\title{
EXPERIMENTAL INVESTIGATION ON LOAD SHARING OF SOIL AROUND PILES AND UNDERNEATH RAFT ON PILE GROUPS
}

\author{
Elsamny, M.K ${ }^{1}$, Ibrahim, M.A ${ }^{2}$, Gad S.A ${ }^{3}$, Abdel-Mageed, M.F ${ }^{4}$ \\ ${ }^{1}$ Civil Engineering department, Faculty of Engineering, Al-Azhar University, Cairo, Egypt \\ ${ }^{2}$ Civil Engineering department, Faculty of Engineering, Al-Azhar University, Cairo, Egypt \\ ${ }^{3}$ Civil Engineering department, Faculty of Engineering, Al-Azhar University, Cairo, Egypt \\ ${ }^{4}$ Civil Engineering department, Faculty of Engineering, Al-Azhar University, Cairo, Egypt
}

\begin{abstract}
Determination of load sharing between soil, piles and underneath pile raft is a complex geotechnical task.Thus, experimental investigation is a simplified method to predict the load sharing between soil, piles and underneath pile raft. The purpose of the current study is to investigate experimentally the load sharing between soil and pile raft in cohesionless soil. The distributions of applying loads to the lower parts of founded soil as well as pile raft were determined by experimental investigation program. The experimental investigation program consisted of testing pile groups of one, two, three, four, five and six piles in sand. The program consisted of installing test piles in dense compacted sand with spacing of three diameters subjected to compressive axial load. The pile head loads, displacement, strains along the piles shaft as well as transferred loads underneath pile raft were measured simultaneously. The loads transferred to soil underneath pile caps (raft) and to soil at pile tips were measured by load cells. In addition, the distribution of loads along pile shaft was determined from five strain gauges readings mounted on the longitudinal reinforcement of piles. Moreover, the sharing loads between resisting soil underneath the caps (raft) and piles have been determined. However, for single pile it was found that the percentage of the transferred load at the pile tip $=13.50 \%$ from the ultimate capacity. In addition, for single pile it was found that the percentage of the transferred load by friction $=86.50 \%$ from the ultimate capacity. For pile groups (2, 3, 4, 5 and 6 piles), it was found that the percentage of loads transferred to the soil underneath the pile caps $=0.88$ to $1.10 \%$ from the ultimate bearing capacity. In addition, for pile groups (2, 3, 4, 5 and 6 piles), it was found that the percentage of loads transferred to the soil at pile tip $=4.20$ to $2.53 \%$ from the ultimate bearing capacity. However, for pile groups (2, 3, 4, 5 and 6 piles), it was found that the percentage of loads transferred to the soil by friction $=94.70$ to $96.59 \%$ from the ultimate bearing capacity.
\end{abstract}

Keywords: Piles; load sharing analysis; loading test; pile groups; strain gauges; experimental.

\section{INTRODUCTION}

There is no simplified method for load sharing prediction between soil and raft on piles. However, experimental investigation is one way to predict the values of loads that transferred to soil through pile shaft (friction), underneath the pile caps (raft) and at the pile tips.

Russo, G. (1998) presented an approximate numerical method for the analysis of piled raft foundations. The raft is modelled as a thin plate and the piles as interacting non linear springs. Both the raft and the piles are interacting with the soil which is modelled as an elastic layer. Two sources of non-linearity are accounted for: (i) the unilateral contact at the raft soil interface and (ii) the non-linear load settlement relationship of the piles [1].

Noh E. Y., et al (2008) presented a finite element analysis on un-piled and piled raft foundations. For the un-piled raft, the normalized settlement parameter (IR) was found to ranged between 1.02-1.15, and $0.64-0.81$. In the case of the piled raft with raft thicknesses of $0.25,0.4,0.8,1.5$ and $3 \mathrm{~m}$, the corresponding maximum settlements are 64, 63.3, 62.6, 62.3 and $62.2 \mathrm{~mm}$, and the bending moment values are 107, 160, 321,446 and $485 \mathrm{kN} . \mathrm{m}[2]$.
Amornfa K., et al (2012) presented a comparative study on the results of the 3 dimensional finite element (3D FEM) analysis and various analysis methods used. The results showed that the plate on pile springs method which neglects pile-pile and raft-pile interaction give results significantly different from that of the 3D FEM. The 3D FEM shows that only about $70-80 \%$ of total building loads are carried by piles when raft is placed in the stiff clay layer. The number of piles in the piled raft foundation can be significantly reduced particularly if the true piled raft foundation concept is adopted, while the foundation settlement only increases slightly [3].

Alnuiam A., et al (2013) established a 3D finite element model to analyze the response piled raft foundation system installed in cohesionless soil with linearly increasing stiffness with depth. The model was calibrated/verified using geotechnical centrifuge test data. The calibrated model was then employed to investigate the effect of raft dimensions and piles diameter and spacing on the load sharing between piles and raft [4]. 
Park, D. et al (2013) presented that in the conventional design for piled rafts, the load capacity of the raft is not in general taken into account and the load capacity of piles is only considered for the estimation of the total load carrying capacity of the piled rafts. As a consequence, piled rafts are often designed with excessively conservative safety margin, raising a need of further investigation of the load capacity mechanism of piled rafts. From the test results, it is revealed that the load carrying capacity increase for piled rafts differ for different soil conditions. The load capacity of piled rafts is greater than those of the group piles by $13 \%$ for dense sand cases and by $22 \%$ for loose sand cases [5].

Park, D. et al (2013) presented that the conventional pile design, pile cap is regarded as a structural member that connects the superstructure and piles, transferring imposed loads to the lower foundation parts. The load carrying capacity of pile cap is not in general taken into account even for direct contact condition with ground surface. In Park, D. et al study; the load carrying behaviors of piled rafts were investigated focusing on the individual load-settlement responses of piles and raft on piled rafts. A settlement-based load sharing model for piled rafts was proposed using the normalized non-linear load-settlement relationship with consideration of piled-raft interaction effect. According to the proposed load sharing model, the load sharing ratio decreases as settlement increases with rates depending on the load capacity ratio. The values of appear higher for higher load capacity ratios [6].

Thakare, S. W., and Pankaj D. (2016) conducted a laboratory study on model piled raft foundation to evaluate the influence of configuration of piles and number of piles of piled raft foundation on ultimate bearing capacity and settlement reduction. In this laboratory study, three sets of model piled raft foundation were studied consisting of 16, 24 and 32 number of piles having $1 / \mathrm{d}$ ratio equal to 40 . In each sets, five different configurations of piles were tested. Pile diameter, pile length, type of soil and size of raft were kept constant. The results of tests conducted on raft and piled raft foundation with different configurations of piles were compared in terms of ultimate bearing capacity, load sharing ratio and settlement reduction ratio. It is concluded that the configurations of piles in a piled raft foundation has significant effect on ultimate bearing capacity, settlement reduction and load sharing ratio between the raft and piles [7].

Ahmadi, M. M. (2016) presented that stiffness of the pile cap also confirmed that it influence significantly the distribution of the structural loads to the individual piles. The results from numerical analysis and full-scale field test were presented to analyse the group efficiency of pile [8].

Elsamny, M. K. et al (2017) investigated the bearing capacity and behaviour of piles in sand for single pile and group of two piles. An experimental research program was conducted to study the distribution of the friction along the pile shaft and the load to be transferred by the tip of the pile in cohesionless soil as well as the group effect of two piles.
The experimental program consisted of testing single and group of two piles in sand under axial compression load. The spacing between piles was three pile diameters. The program consisted of installing test piles in dense sand placed in a soil chamber [9].

Elsamny, M. K. et al (2017) investigated the ultimate capacity, settlement and efficiency of pile groups in sandy soil. An experimental program was conducted to study the group effect on ultimate capacity, settlement and efficiency. However, the experimental program consisted of testing single pile and pile groups of two, three and four piles in sand under axial compression load. The spacing between piles was three pile diameters. The pile head loads, displacement, strains along the piles shaft were measured simultaneously. The obtained test results indicated that the ultimate capacity of single pile inside pile groups increases with increasing number of piles. However, the settlement of pile groups at the ultimate load was found to be more than that of the settlement of single pile. In addition, it was found that group efficiency of pile groups (2, 3 and 4 piles) increases with increasing the number of piles. However, for number of piles in pile group more than four no significant increase has been obtained. In addition, the group efficiency was found to be ranging from $1.25-1.47$ as by using modified chin method (1970) for the determination of ultimate capacity of piles [10].

However, the purpose of the present study is to investigate the effect of number of piles in pile groups on the load sharing that transferred to soil around pile shaft, underneath the pile caps and to soil at the pile tip.

\section{INVESTIGATION EXPERIMENTAL}

\section{PROGRAM}

The investigation experimental program was conducted to study the effect of number of piles on load sharing of soil around piles and underneath the caps of the pile groups. The piles were instrumented by five strain gauges along the steel reinforcement to measure thedistribution of loads in pile at different levels of single pile and pile groups. The piles were tested in a setup under compressive axial loads. The strains along the piles and loads at the pile tip and underneath the pile caps as well as settlement were measured simultaneously. The test piles were installed in dense compacted sand. The sand was placed and compacted in fifteen centimeters layers using mechanical compactor. The densities of the compacted sand were measured by sand cone tests. In total, six load tests were performed in axial compression. First load test was carried out on single pile while the second, third, fourth, fifth and sixth loading tests were carried out on pile groups of two, three, four, five and six piles. The load capacities of the piles were established. However, the loads at pile tips and underneath the pile caps were measured by load cells.

The test program was carried out on the followings:

- Group (1) - Single pile

- Group (2) - Group of two piles 
- Group (3) - Group of three piles

- Group (4) - Group of four piles

- Group (5) - Group of five piles

- Group (6) - Group of six piles

\subsection{Piles Used Materials}

a. The coarse aggregate used in the concrete mix was crushed stone, while the fine aggregates was graded sand.

b. The ordinary portland cement was used. However, the average nominal cube strength was found to be $2.00 \mathrm{kN} / \mathrm{cm} 2$ c. Five hot rolled reinforcement steel bars were used as reinforcement for all specimens.

\subsection{Concrete Dimensions}

A total of twenty one precast concrete cylindrical piles with (150) $\mathrm{mm}$ outside diameter and (1500) $\mathrm{mm}$ length were casted. Pile concrete dimensions and reinforcement details are shown in Figures. (1) to (6) for single pile, group of two piles, group of three piles, group of four, group of five piles and group of six piles respectively.

\subsection{Strain Gauges for Measurement of Strains}

The strain gauges were mounted on the longitudinal steel reinforcement as shown in Figure(7). The strain gauges wires were connected to a strain indicator.

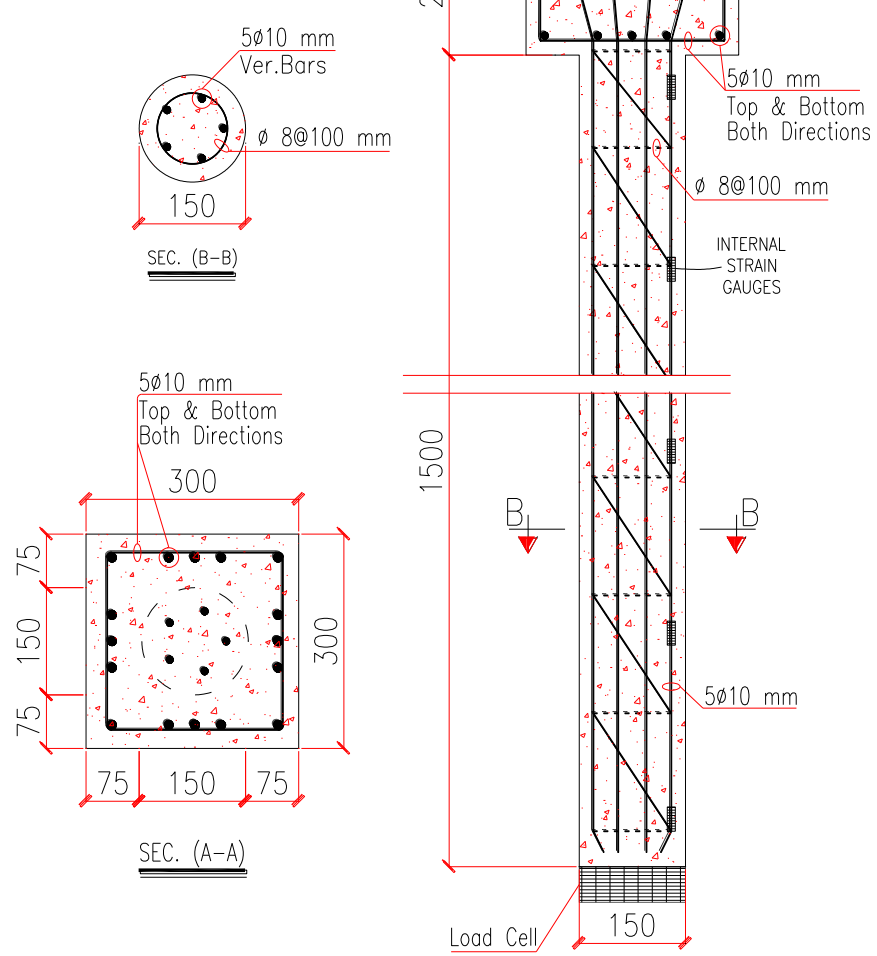

Fig 1: Concrete dimension and reinforcement for group (1) single pile

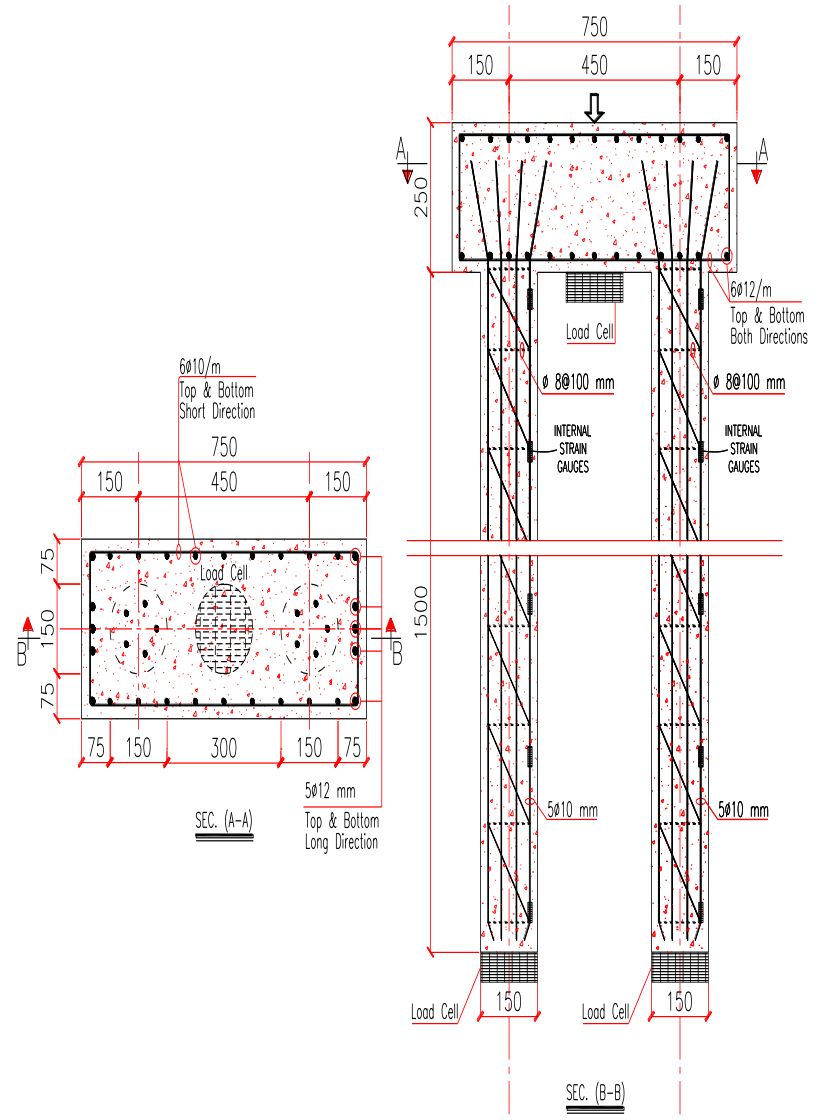

Fig 2: Concrete dimension and reinforcement for group (2) group of two piles

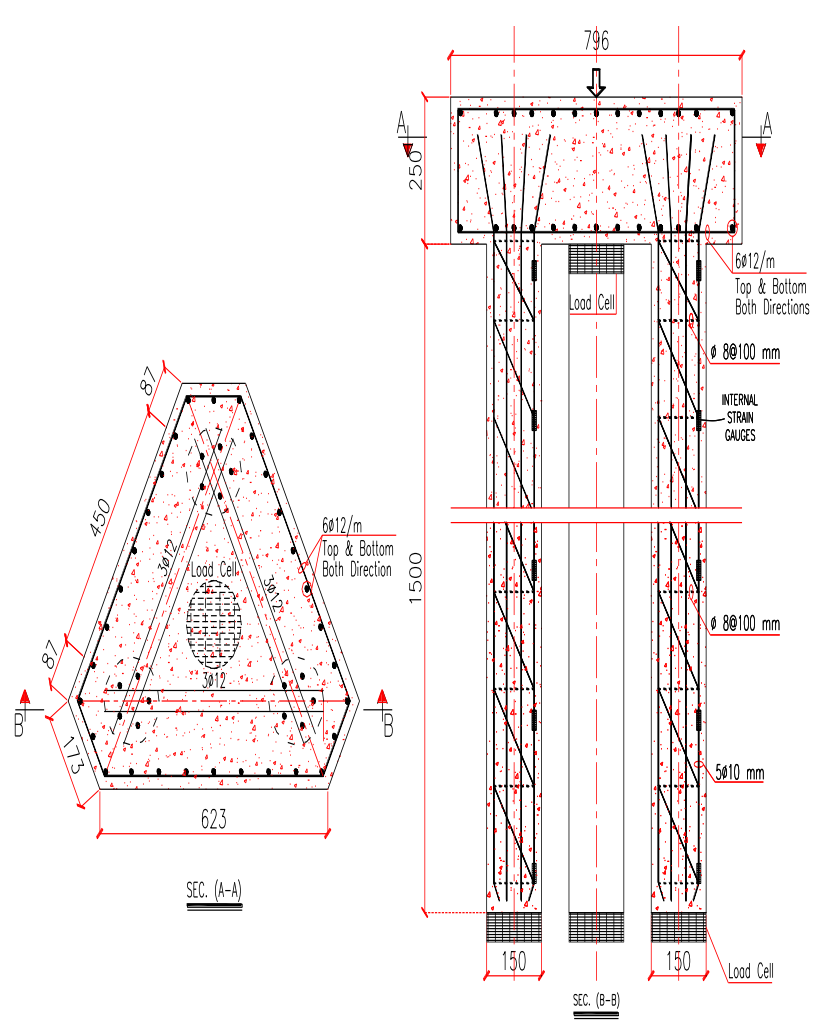

Fig 3: Concrete dimension and reinforcement for group (3) group of three piles 


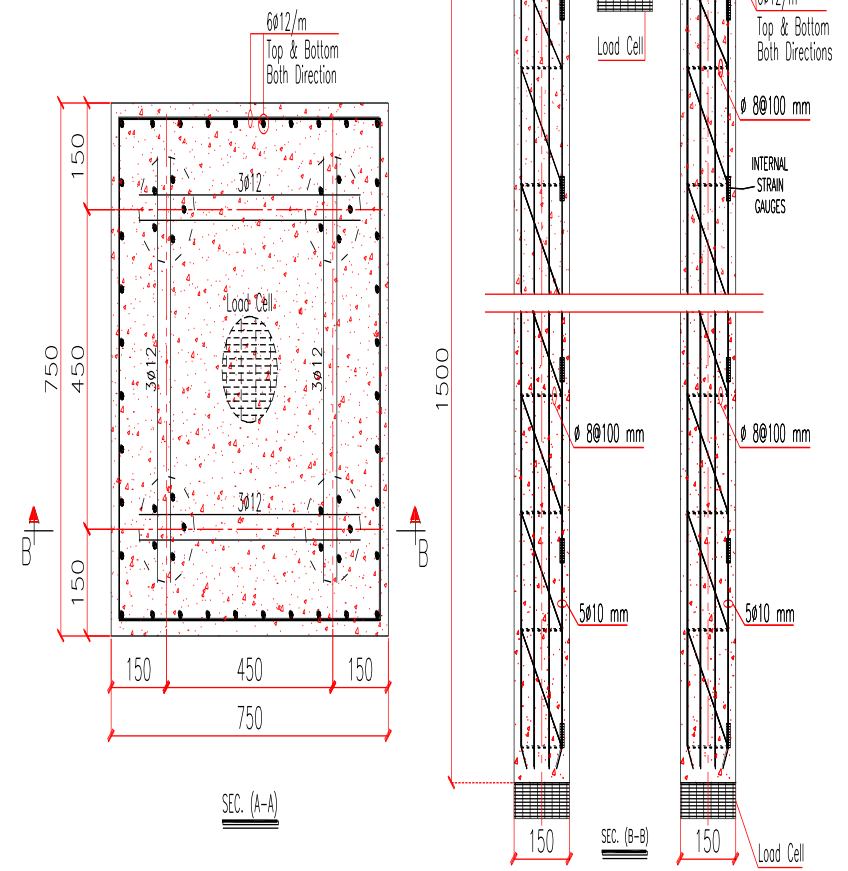

Fig 4: Concrete dimension and reinforcement for group (4) four piles

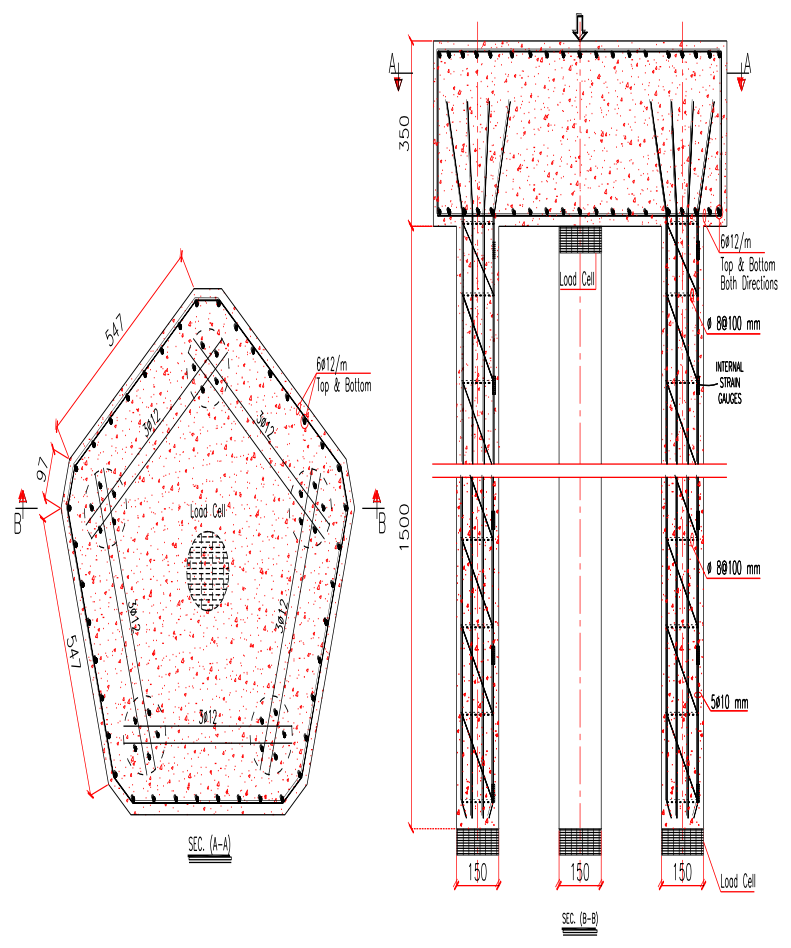

Fig 5: Concrete dimension and reinforcement for group (5) five piles

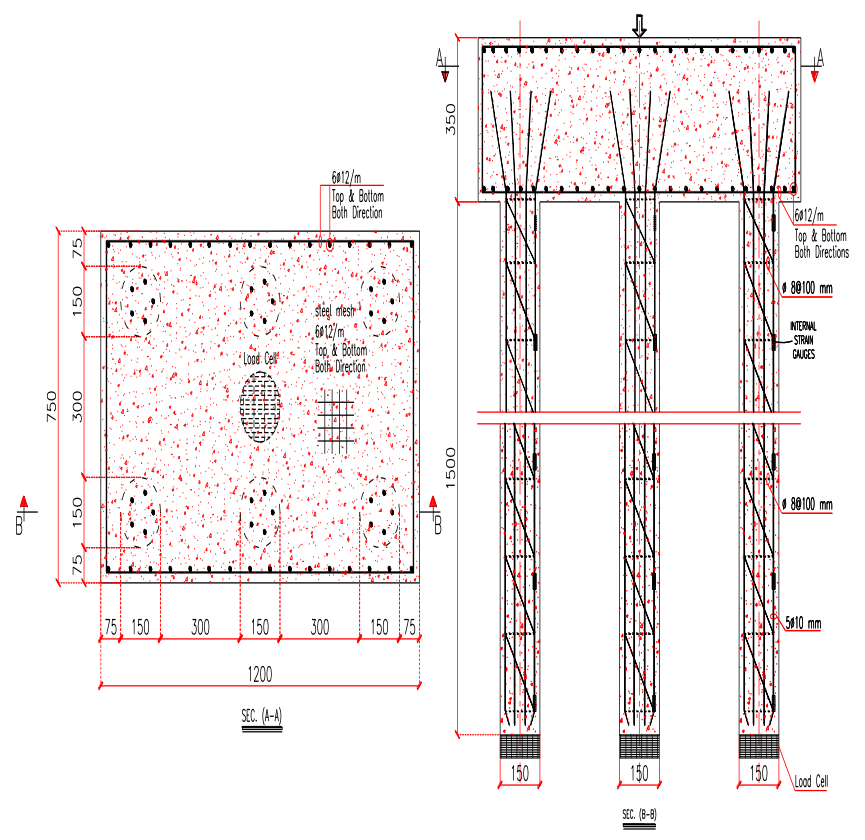

Fig 6: Concrete dimension and reinforcement for group (6) six piles

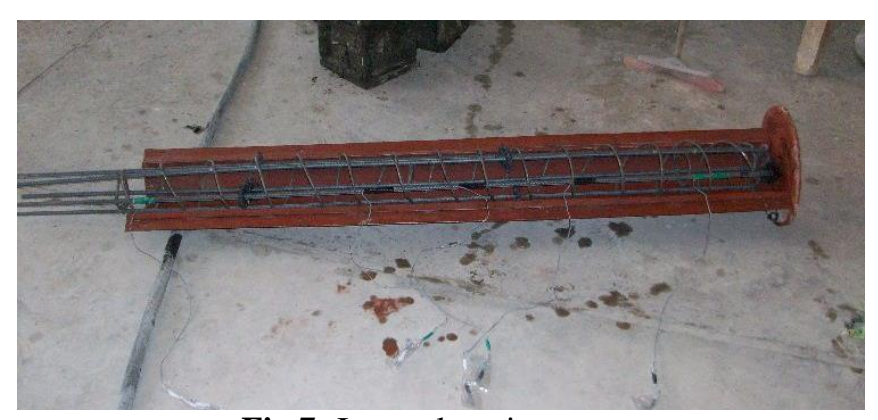

Fig 7: Internal strain gauges

\subsection{Casting of Piles}

All specimens were casted in cylindrical tubes (forms) shown in Figure(8). A mechanical vibrator was used as shown in Figure(9).

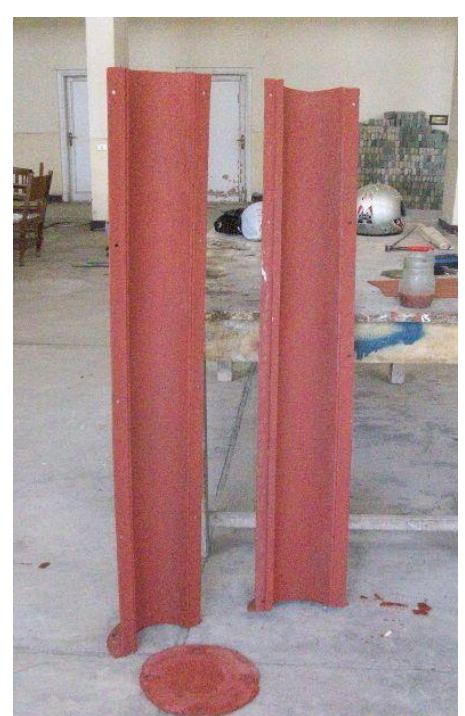

Fig 8: Description of forms 


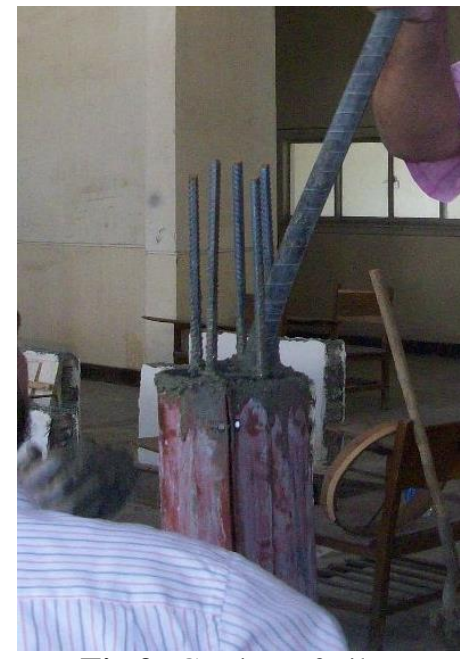

Fig 9: Casting of piles

\section{PILE LOADS FOR SINGLE PILE FROM}

\section{THEORETICAL APPROACHES}

Table (1) summaries the calculated theoretical ultimate capacities for single pile.

Table 1: Ultimate single pile loads from theoretical approaches

\begin{tabular}{|l|l|}
\hline Method & Ult. load -single pile (kN) \\
\hline Egyptian Code (2001) & 30.00 \\
\hline Meyerhof (1976) & 29.00 \\
\hline Vesic (1977) & 25.00 \\
\hline Janbu (1976) & 39.00 \\
\hline Coyle and Castello (1981) & 25.00 \\
\hline
\end{tabular}

\section{PROCEDURE OF TESTING PILES}

The pile groups were divided in six groups as follows:

-Group (1) - Single pile

-Group (2) - Group of two piles

-Group (3) - Group of three piles

-Group (4) - Group of four piles

-Group (5) - Group of five piles

-Group (6) - Group of six piles

Pile groups (1) and (2) were loaded up to 1.50 time's ultimate load in 12 increments while groups from (3) to (6) were loaded up to 1.75 time's ultimate load according to the Egyptian Code, 2001. So,each increment was maintained for as certain time as shown in Table (2). The measurements of load at top of pile were recorded. Dial gauges readings were taken for each loading increment for settlement measurement. However, load cells were placed at the tip of piles and underneath the pile caps to measure the transferred load to soil. In addition, strains readings along pile shaft were recorded. Table (3)shows the experimental program and the theoretical calculated ultimate load values from different theoretical methods for single pile and pile groups of two, three, four, five and six piles.
Table 2: Increment of load and minimum interval time for each according to Egyptian code (2001) for tested pile groups

\begin{tabular}{|c|c|c|c|c|}
\hline & \multicolumn{2}{|c|}{ Test load $=1.50$ Qult } & \multicolumn{2}{|c|}{ Test load $=1.75$ Qult } \\
\hline \multirow{8}{*}{ 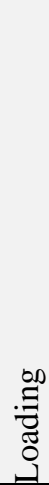 } & Load \% & Time & Load \% & Time \\
\hline & 25 & $1.00 \mathrm{hr}$ & 25 & $1.00 \mathrm{hr}$ \\
\hline & 50 & $1.00 \mathrm{hr}$ & 50 & $1.00 \mathrm{hr}$ \\
\hline & 75 & $1.00 \mathrm{hr}$ & 75 & $1.00 \mathrm{hr}$ \\
\hline & 100 & $3.00 \mathrm{hrs}$ & 100 & $3.00 \mathrm{hrs}$ \\
\hline & 125 & $3.00 \mathrm{hrs}$ & 125 & $3.00 \mathrm{hrs}$ \\
\hline & 150 & $12.00 \mathrm{hrs}$ & 150 & $3.00 \mathrm{hrs}$ \\
\hline & & & 175 & $12.00 \mathrm{hrs}$ \\
\hline \multirow{8}{*}{ 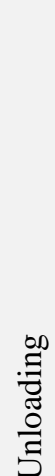 } & Load \% & Time & Load $\%$ & Time \\
\hline & & & 150 & $15 \mathrm{~min}$. \\
\hline & 125 & $15 \mathrm{~min}$. & 125 & $15 \mathrm{~min}$. \\
\hline & 100 & $15 \mathrm{~min}$. & 100 & $15 \mathrm{~min}$. \\
\hline & 75 & $15 \mathrm{~min}$. & 75 & $15 \mathrm{~min}$. \\
\hline & 50 & $15 \mathrm{~min}$. & 50 & $15 \mathrm{~min}$. \\
\hline & 25 & $15 \mathrm{~min}$. & 25 & $15 \mathrm{~min}$. \\
\hline & 0 & $4.00 \mathrm{hrs}$ & 0 & $4.00 \mathrm{hrs}$ \\
\hline
\end{tabular}

\subsection{Loading Frame}

Loading frame was manufactured to resist the expected maximum loads that might occur during the test as shown in Figure(10).

\subsection{Loading Jack}

The testing load was applied using a $1000 \mathrm{kN}$ hydraulic jack located at the top of the tested pile or piles group as shown in Figure(11).

Table 3: Theoretical calculated ultimate loads Values from different methods

\begin{tabular}{|c|c|c|c|c|c|c|}
\hline \multirow{2}{*}{$\begin{array}{l}\mathfrak{\Xi} \\
\stackrel{0}{0} \\
0\end{array}$} & \multirow{2}{*}{ Pile Arrangement } & \multicolumn{5}{|c|}{ Qult (Theoretical) (kN) } \\
\hline & & $(1)$ & $(2)$ & (3) & $(4)$ & $(5)$ \\
\hline $\begin{array}{l}\overparen{\Xi} \\
\varsubsetneqq \\
\vdots \\
0 \\
0\end{array}$ & 60 & 30 & 29 & 25 & 39 & 25 \\
\hline 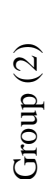 & 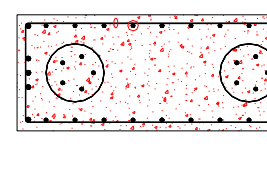 & 60 & 58 & 50 & 78 & 50 \\
\hline
\end{tabular}




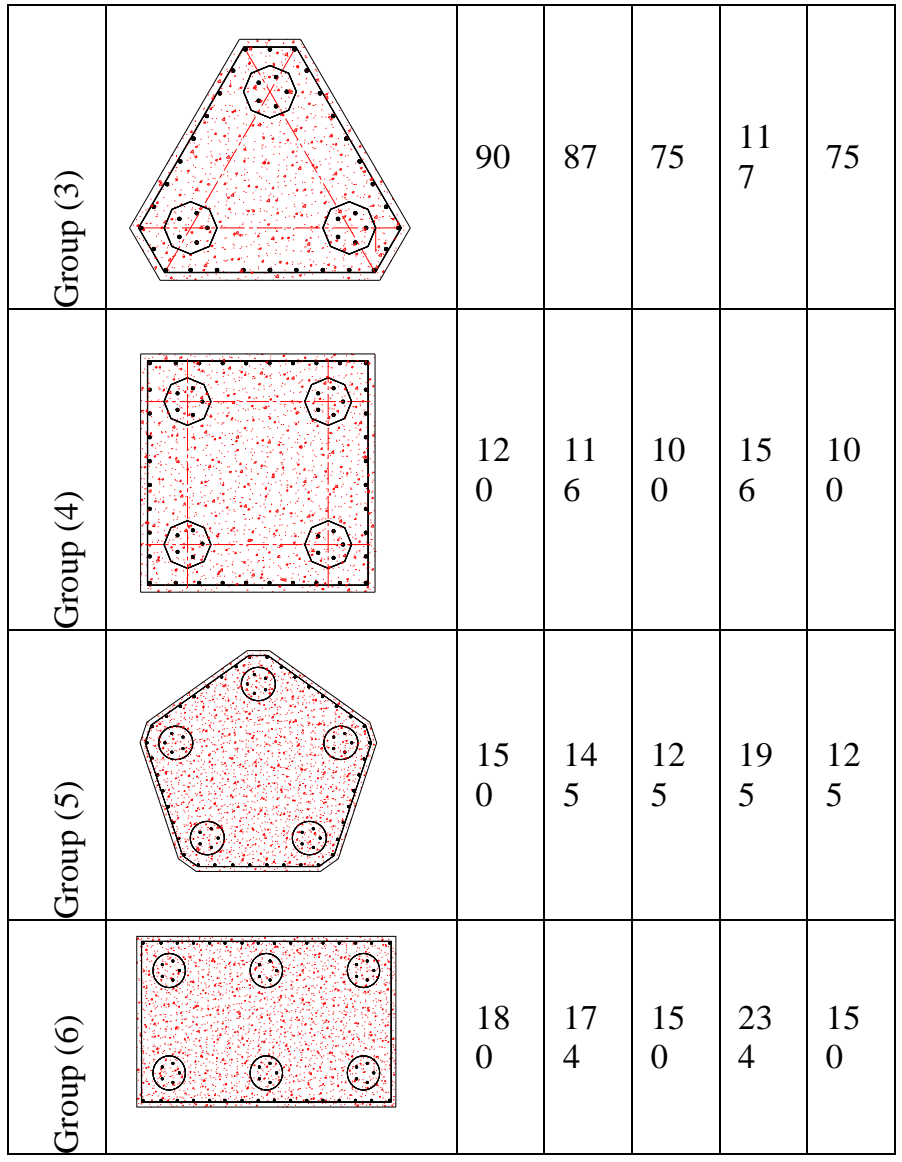

Where:

Egyptian Code (2001), [11]

Meyerhof (1976), [12]

Vesic (1977), [13]

Janbu (1976), [14]

Coyle and Castello (1981), [15]

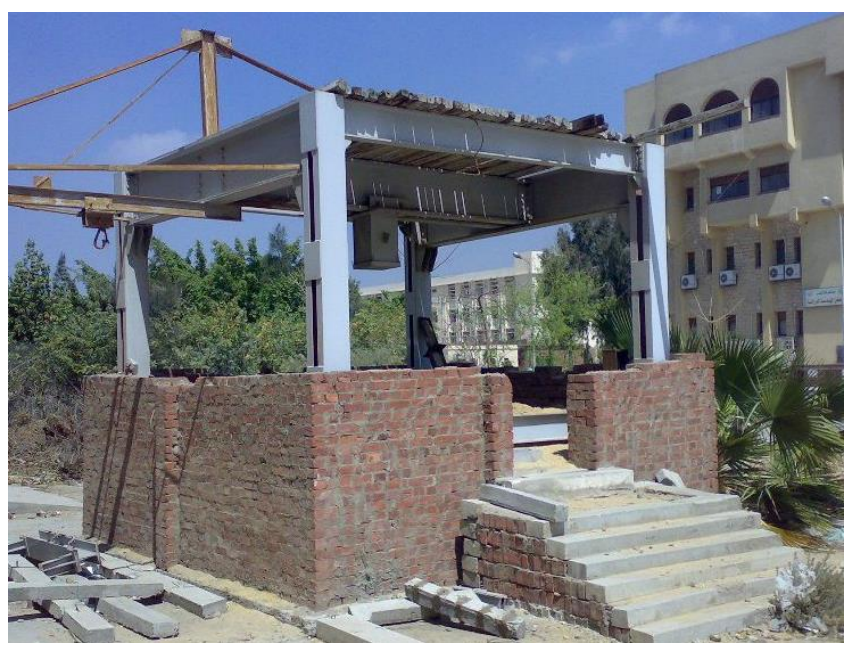

Fig 10: Loading frame

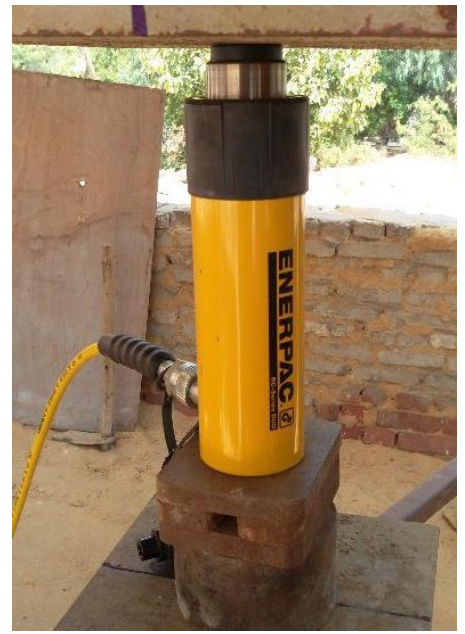

Fig 11: Loading jack

\subsection{Load Measurements}

The load was measured at the tip of piles and underneath the pile caps by an $800 \mathrm{kN}$ load cells connected to the data acquisition system as shown in Figures(12) and(13).

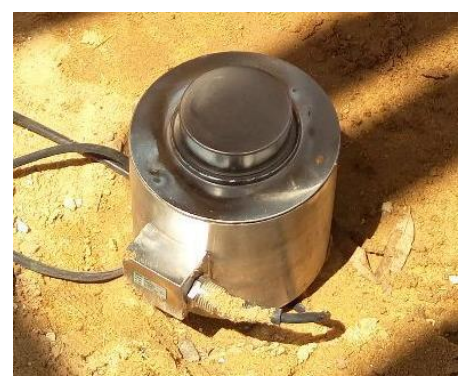

Fig 12: Load cell

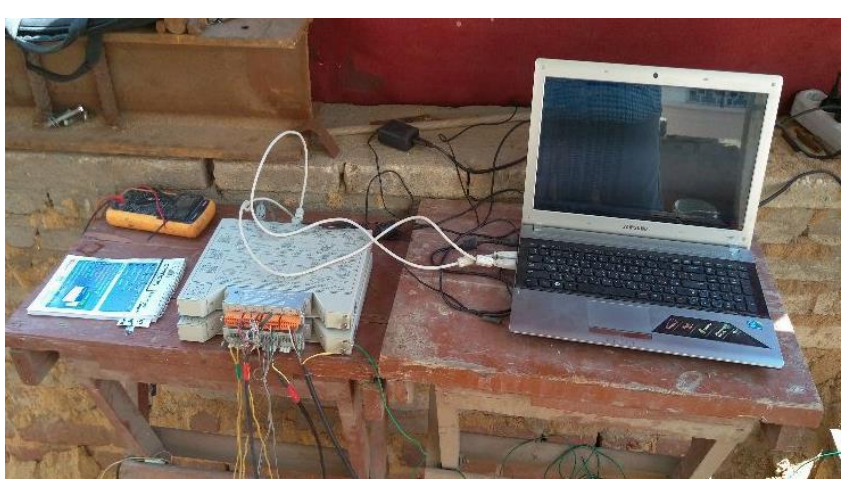

Fig 13: Data acquisition system

\subsubsection{Group (1) - Single Pile}

The pile was embedded in the sand such that the total embedment depth of the pile was $1500 \mathrm{~mm}$ after filling the soil chamber with $150 \mathrm{~mm}$ compacted layers of sand using mechanical compactor as shown in Figure(14). Moreover, the vertical displacements of the pile cap were measured by four dial gauges with accuracy of $0.01 \mathrm{~mm}$ as shown in Figure(15). 


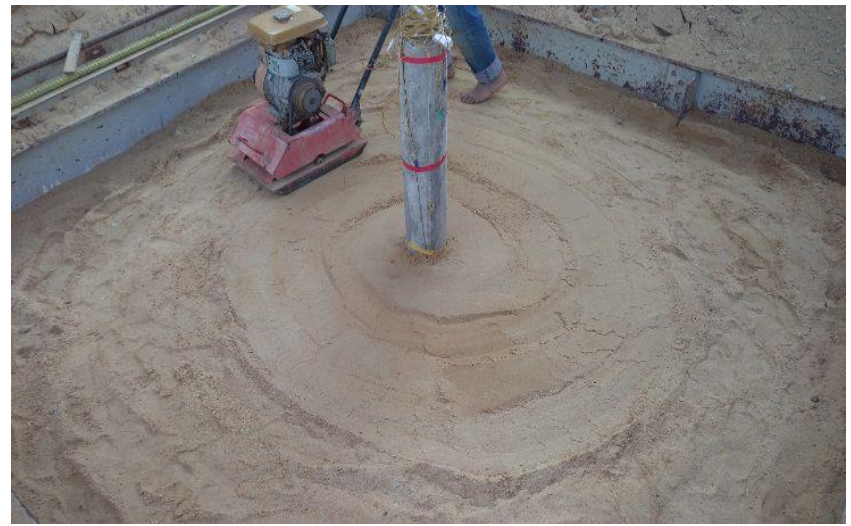

Fig 14: Placing compacted soil around tested pile for group (1) - single pile

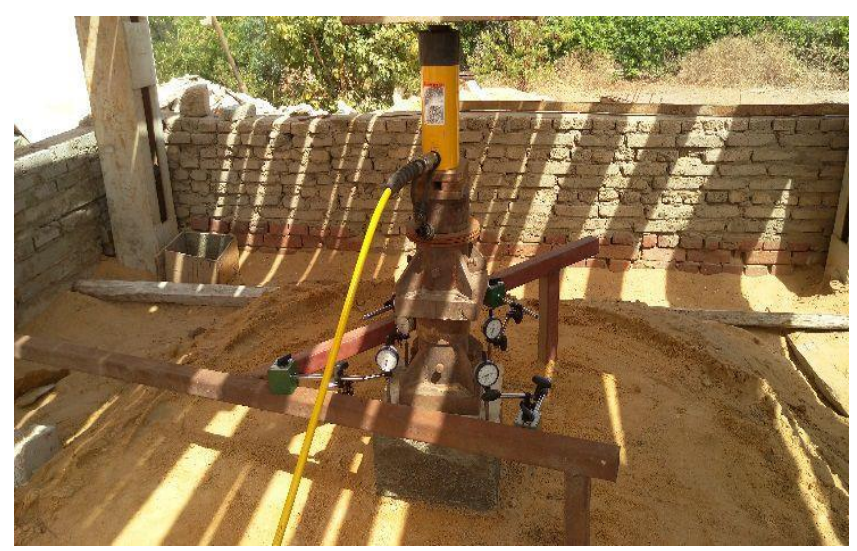

Fig 15: Reference beam and dial gauges setup for group (1) $-($ single pile)

\subsubsection{Group (2) - Group of Two Piles}

The piles were embedded in the sand such that the total embedment depth of the piles was $1500 \mathrm{~mm}$ after filling the soil chamber with $150 \mathrm{~mm}$ compacted layers of sand using mechanical compactor as shown in Figure (16). Moreover, the vertical displacements of the pile cap were measured by six dial gauges with accuracy of $0.01 \mathrm{~mm}$ as shown in Figure (17).

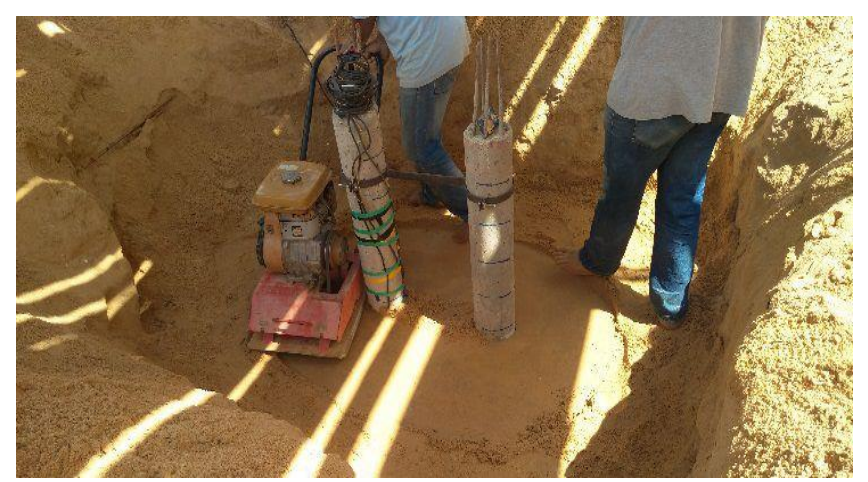

Fig 16: Placing compacted soil around tested pile groups for group (2) - group of two piles

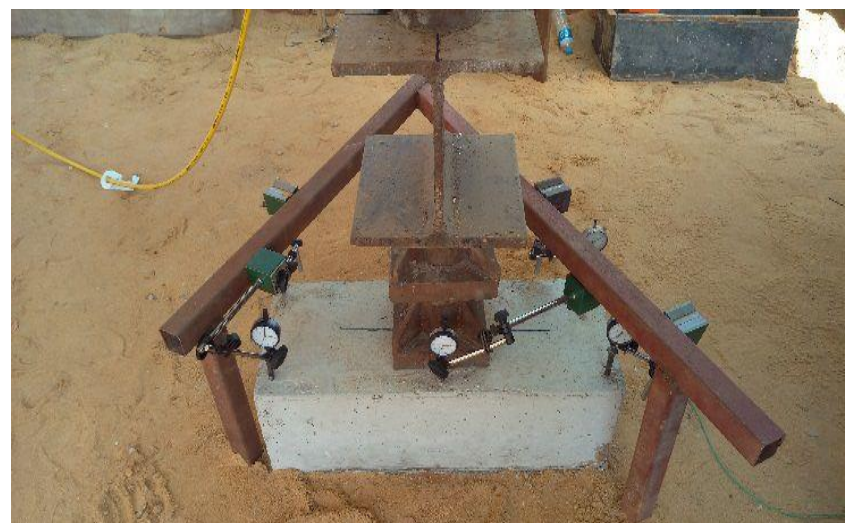

Fig 17: Loading jack and dial gauges setup for group (2) group of two piles

\subsubsection{Group (3) - Group of Three Piles}

The piles were embedded in the sand such that the total embedment depth of the piles was $1500 \mathrm{~mm}$ after filling the soil chamber with $150 \mathrm{~mm}$ compacted layers of sand using mechanical compactor as shown in Figure(18). Moreover, the vertical displacements of the pile cap were measured by six dial gauges with accuracy of $0.01 \mathrm{~mm}$ as shown in Figure(19).

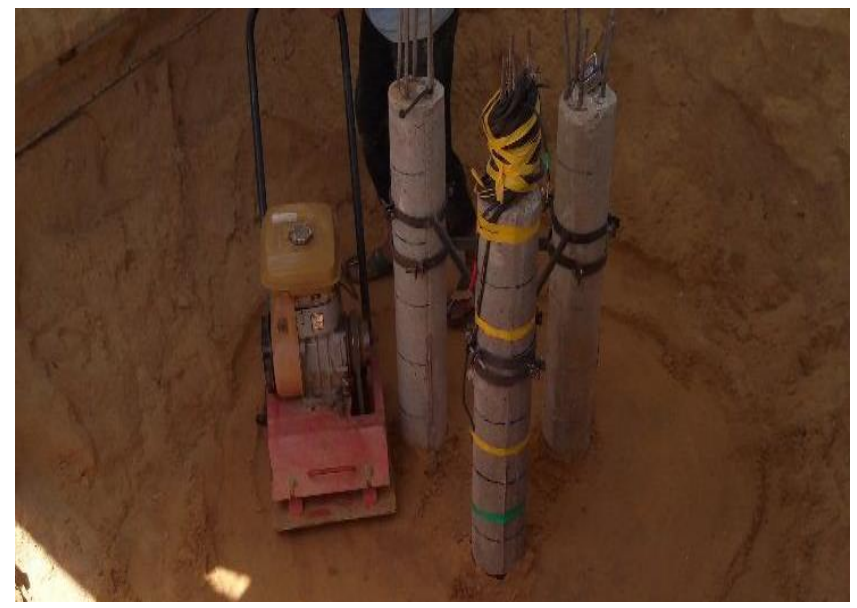

Fig 18: Placing compacted soil around tested pile groups for group (3) - group of three piles

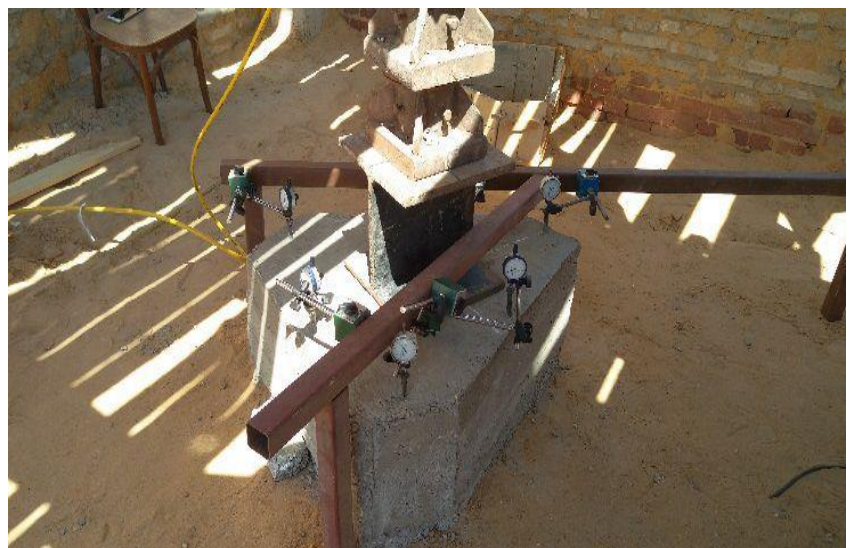

Fig 19: Loading jack and dial gauges setup for group (3) group of three piles 


\subsubsection{Group (4) - Group of Four Piles}

The piles were embedded in the sand such that the total embedment depth of the piles was $1500 \mathrm{~mm}$ after filling the soil chamber with $150 \mathrm{~mm}$ compacted layers of sand using mechanical compactor as shown in Figure(20). Moreover, the vertical displacements of the pile cap were measured by six dial gauges with accuracy of $0.01 \mathrm{~mm}$ as shown in Figure(21).

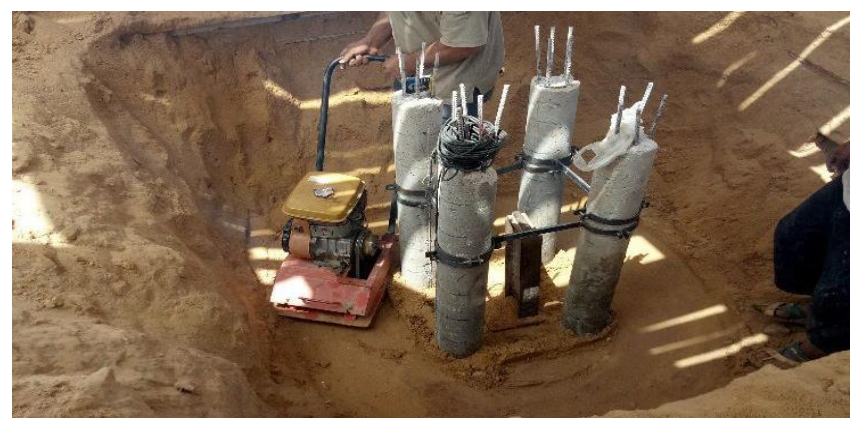

Fig 20: Placing compacted soil around tested pile groups for group (4) - group of four piles

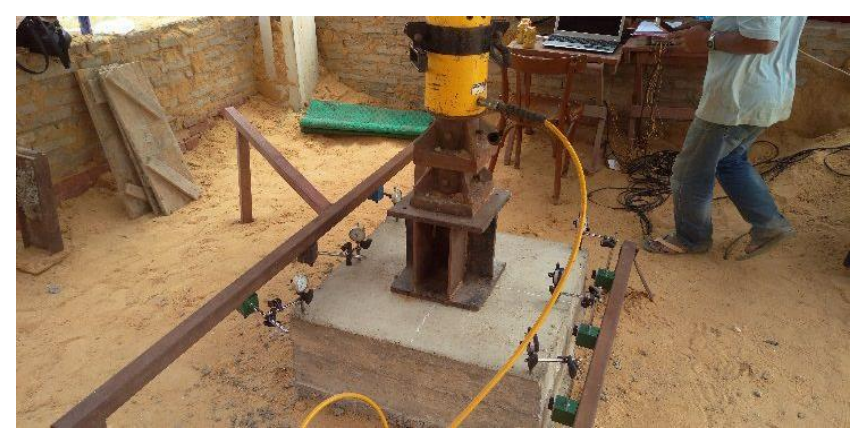

Fig 21: Loading jack and dial gauges setup for group (4) group of four piles

\subsubsection{Group (5) - Group of Five Piles}

The piles were embedded in the sand such that the total embedment depth of the piles was $1500 \mathrm{~mm}$ after filling the soil chamber with $150 \mathrm{~mm}$ compacted layers of sand using mechanical compactor as shown in Figure(22). Moreover, the load transferred to soil underneath the pile cap was measured by load cell as shown in Figure (23). The vertical displacements of the pile cap were measured by six dial gauges with accuracy of $0.01 \mathrm{~mm}$ as shown in Figure(24).

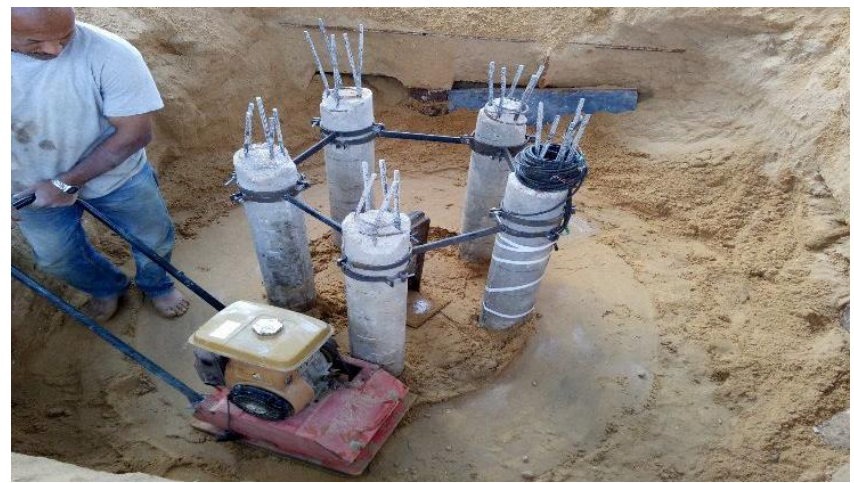

Fig 22: Placing soil around piles for group (5) - group of five piles

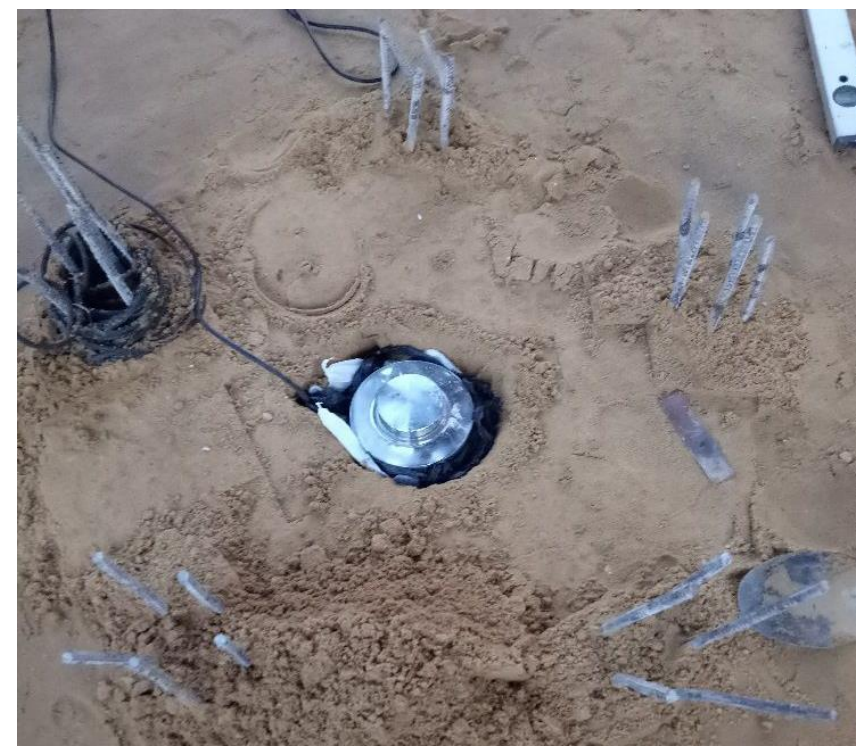

Fig 23: Load cell underneath the pile cap for group (5) group of five piles

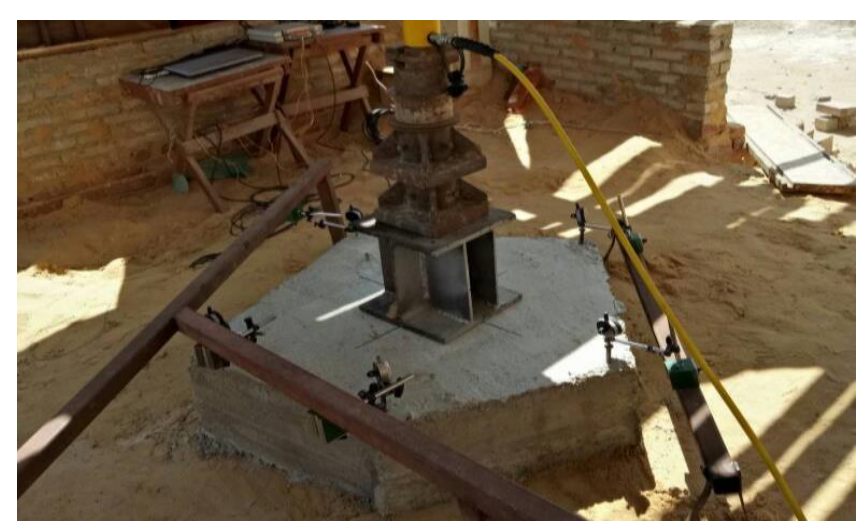

Fig 24: Loading jack, reference beam and dial gauges setup for group (5) - group of five piles

\subsubsection{Group (6) - Group of Six Piles}

The piles were embedded in the sand such that the total embedment depth of the piles was $1500 \mathrm{~mm}$ after filling the soil chamber with $150 \mathrm{~mm}$ compacted layers of sand using mechanical compactor as shown in Figure(25). Moreover, the load transferred to soil underneath the pile cap was measured by load cell as shown in Figure (26). The vertical displacements of the pile cap were measured by six dial gauges with accuracy of $0.01 \mathrm{~mm}$ as shown in Figure(27).

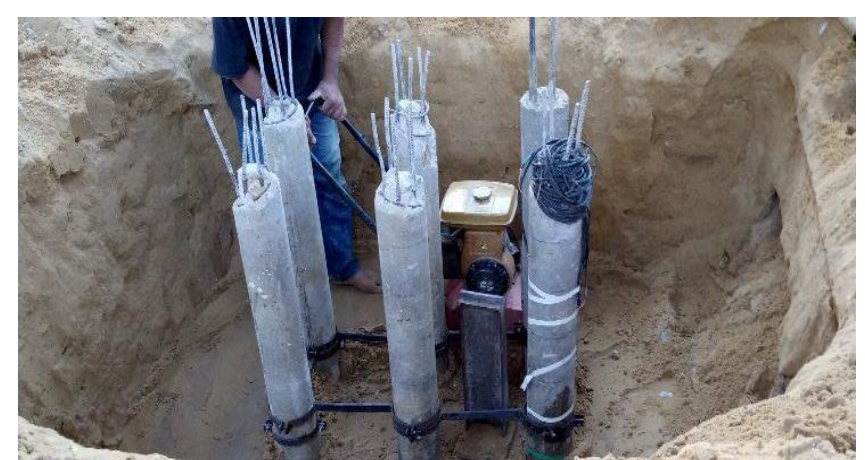

Fig 25: Placing soil around piles for group (6) - group of six piles 


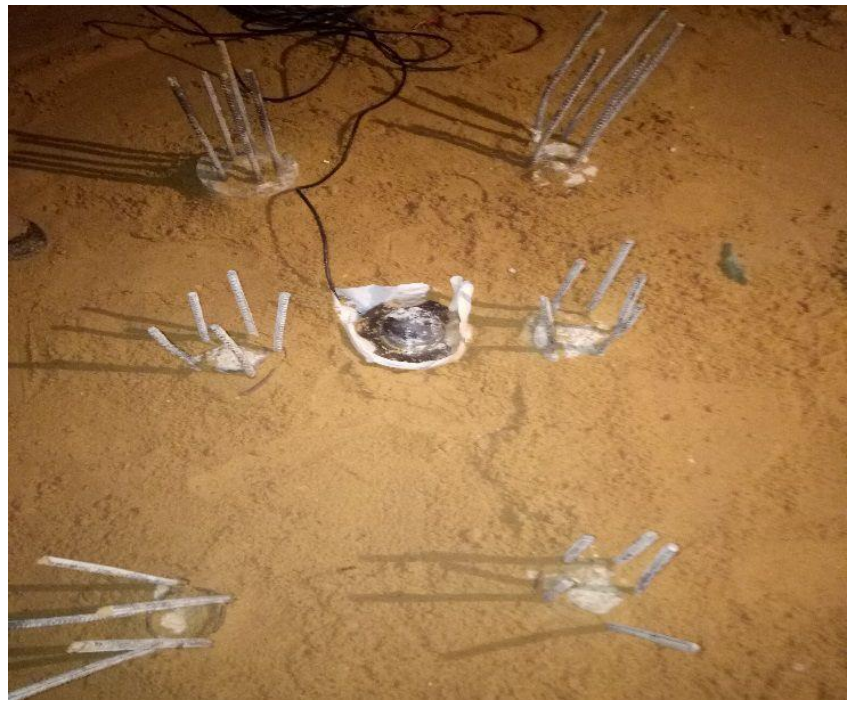

Fig 26: Load cell underneath the pile cap for group (6) group of six piles

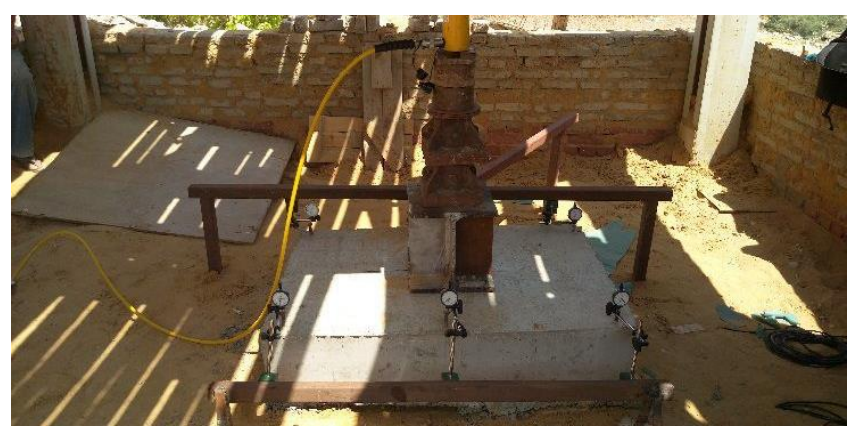

Fig 27: Loading jack, reference beam and dial gauges setup for group (6) - group of six piles

\section{DETERMINATION OF ULTIMATE CAPACITY OF PILES}

Tangent-Tangent method has been used for ultimate pile capacity determination as follows:

Slope tangent from load settlement readings at the point of intersection of the initial and final tangents of the load settlement curve. This point is marked by a vertical arrow at the ultimate capacity.

\section{EXPERIMENTAL TEST RESULTS}

The followings were obtained:

For single pile, the ultimate load was determined by the slope tangent method from load settlement readings at the point of intersection of the initial and final tangents of the load settlement curve. This point is marked in Figure (28) for single pile by a vertical arrow at a load of $29 \mathrm{kN}$. However, the ultimate capacities were determined for groups of $(2,3$, 4, 5 and 6 piles) as shown in Figures (29) to (33) and the values of ultimate capacities are listed in Table [4].

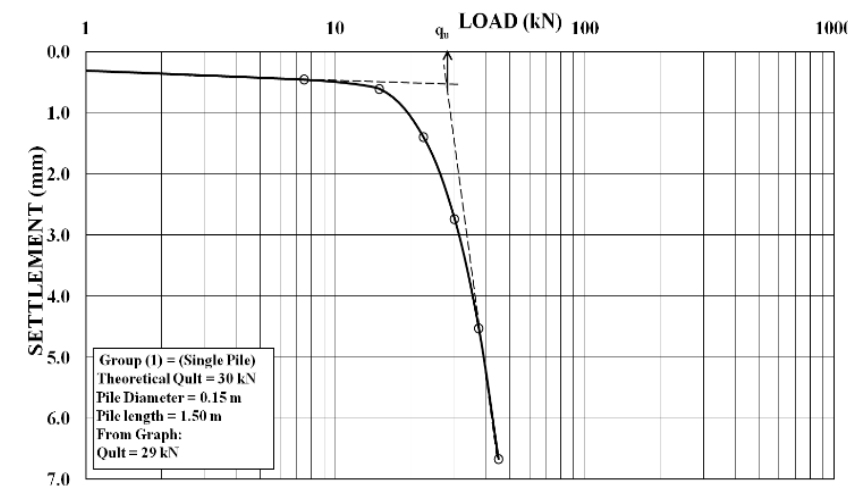

Fig 28: Determining the ultimate capacity by tangent method for group (1) - single pile

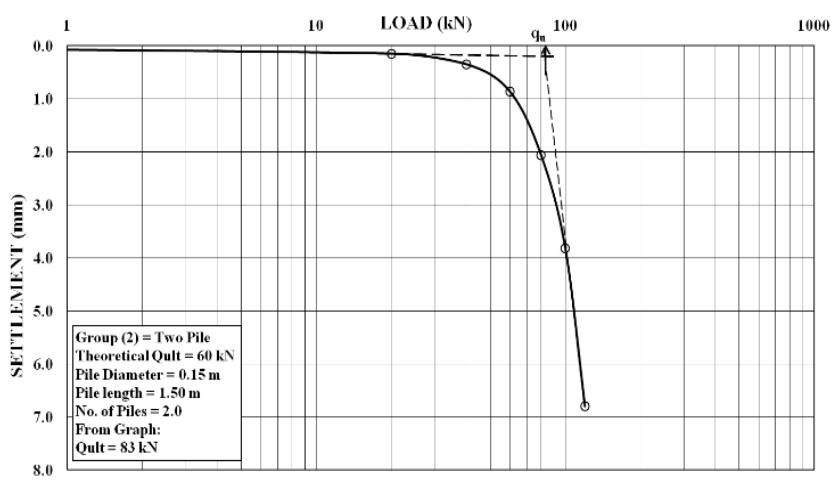

Fig 29: Determining the ultimate capacity by tangent method for group (2) - group of two piles

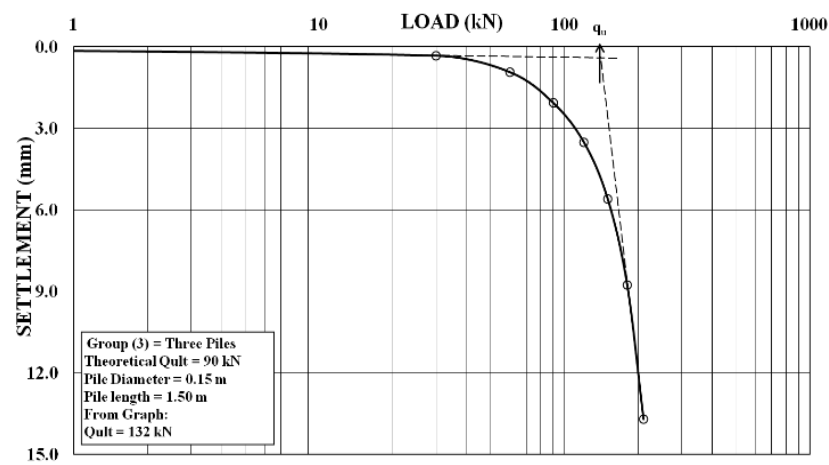

Fig 30: Determining the ultimate capacity by tangent method for group (3) - group of three piles

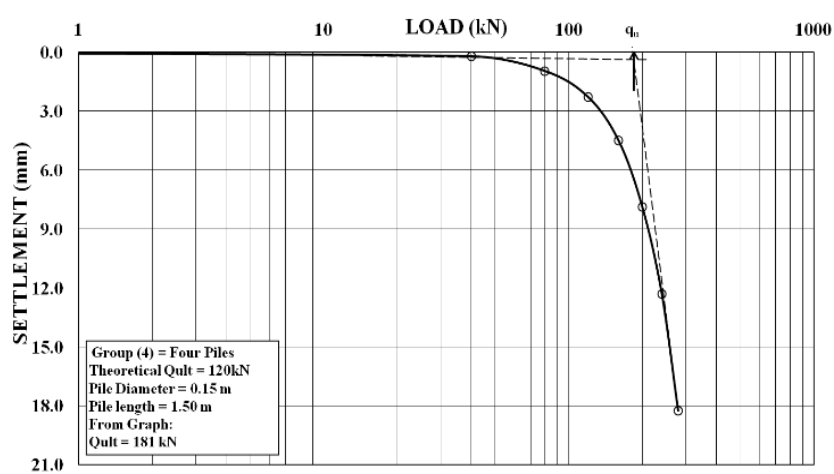

Fig 31: Determining the ultimate capacity by tangent method for group (4) - group of four piles 


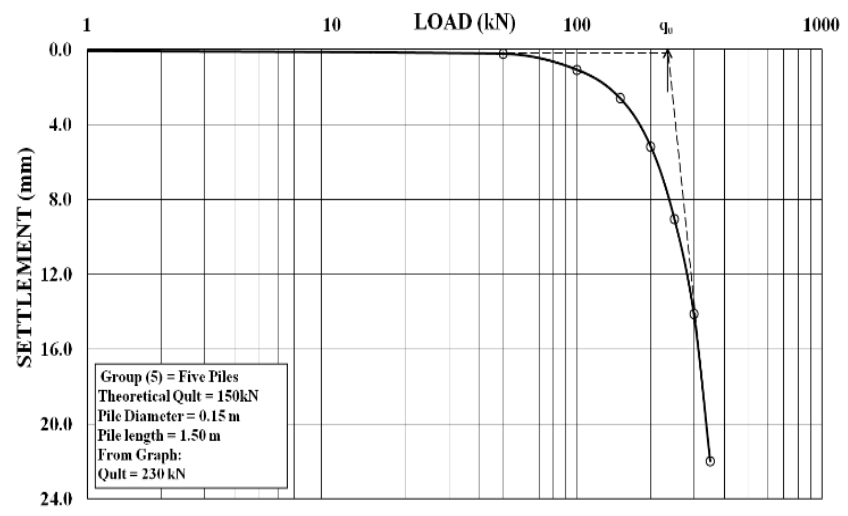

Fig 32: Determining the ultimate capacity by tangent method for group (5) - group of five piles

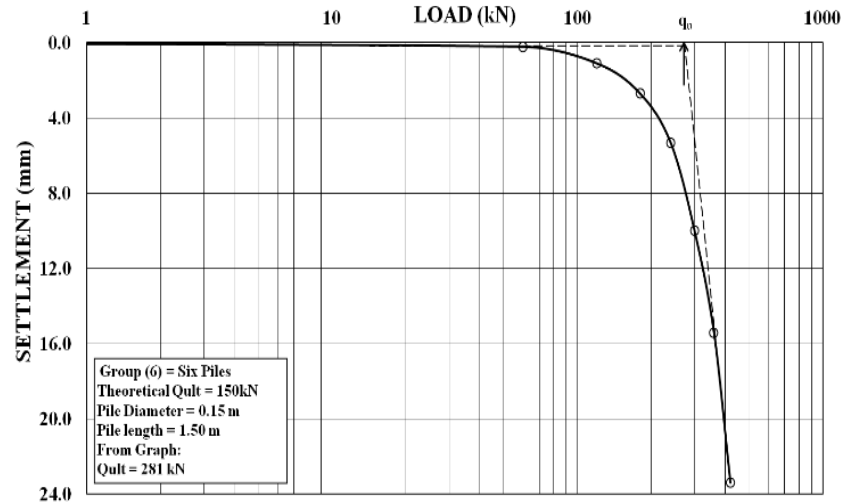

Fig 33: Determining the ultimate capacity by tangent method for group (6) - group of six piles

Table 4: Ultimate capacities of single pile and pile groups by tangent-tangent method

\begin{tabular}{|c|c|}
\hline Group & $\begin{array}{c}\text { Ultimate } \\
\text { capacity }(\mathrm{kN})\end{array}$ \\
\hline Group (1) (single pile) & 29.00 \\
\hline Group (2) (group of two piles) & 83.00 \\
\hline Group (3) (group of three piles) & 132.00 \\
\hline Group (4) (group of four piles) & 181.00 \\
\hline Group (5) (group of five piles) & 230.00 \\
\hline Group (6) (group of six piles) & 281.00 \\
\hline
\end{tabular}

For single pile and pile groups of (2, 3, 4, 5 and 6 piles), the values of transferred load to soil underneath pile caps and at tip of the pile as percentage of ultimate load measured from load cell are listed in Table (5). In addition, the values of transferred load to soil underneath pile caps and at tip of the pile as percentage of working load measured from load cell are listed in Table (6) The relationships between applying load at pile head and transferred loads to soil at pile tips and underneath the pile caps from load cells are shown in Figures (34) to (39).
Table 5: The percentage of load transferred to soil underneath pile cap, at pile tip and around pile shaft (friction) as a percentage of ultimate loads of single pile and pile groups $(2,3,4,5$ and 6 piles) based on results of tangent-tangent method

\begin{tabular}{|l|l|l|l|l|}
\hline \multirow{3}{*}{ Group } & \multicolumn{2}{|l|}{$\begin{array}{l}\text { Transferred load as of load } \\
\text { at head of pile to soil at } \\
\text { ultimate loads }\end{array}$} & \multirow{2}{*}{$\begin{array}{l}\text { Qult } \\
\text { (kN) }\end{array}$} \\
\cline { 2 - 5 } & $\begin{array}{l}\text { Around } \\
\text { pile } \\
\text { (friction) }\end{array}$ & $\begin{array}{l}\text { Underneath } \\
\text { pile cap }\end{array}$ & $\begin{array}{l}\text { At } \\
\text { pile } \\
\text { tip }\end{array}$ & \\
\hline Group (1) & 86.50 & - & 13.50 & 29.00 \\
\hline Group (2 & 94.70 & 1.10 & 4.20 & 83.00 \\
\hline Group (3) & 95.15 & 1.03 & 3.82 & 132.00 \\
\hline Group (4) & 95.30 & 0.94 & 3.76 & 181.00 \\
\hline Group (5) & 96.33 & 0.90 & 2.77 & 230.00 \\
\hline Group (6) & 96.59 & 0.88 & 2.53 & 281.00 \\
\hline
\end{tabular}

Table 6: The percentage of load transferred to soil underneath pile cap, at pile tip and around pile shaft (friction) as a percentage of working loads of single pile and pile groups $(2,3,4,5$ and 6 piles) based on results of tangent-tangent method

\begin{tabular}{|l|l|l|l|l|}
\hline \multirow{3}{*}{ Group } & \multicolumn{2}{|l|}{$\begin{array}{l}\text { Transferred load as of load } \\
\text { at head of pile to soil at } \\
\text { working loads }\end{array}$} & \multirow{2}{*}{$\begin{array}{l}\text { Qworking } \\
\text { (kN) }\end{array}$} \\
\cline { 2 - 4 } & $\begin{array}{l}\text { Around } \\
\text { pile } \\
\text { (friction) }\end{array}$ & $\begin{array}{l}\text { Underneath } \\
\text { pile cap }\end{array}$ & $\begin{array}{l}\text { At } \\
\text { pile } \\
\text { tip }\end{array}$ & \\
\hline Group (1) & 80.00 & - & 20.00 & 9.67 \\
\hline Group (2 & 92.12 & 2.15 & 5.73 & 27.67 \\
\hline Group (3) & 93.11 & 2.10 & 4.79 & 44.00 \\
\hline Group (4) & 93.38 & 1.97 & 4.65 & 60.33 \\
\hline Group (5) & 93.83 & 1.88 & 4.29 & 76.67 \\
\hline Group (6) & 94.30 & 1.76 & 3.94 & 93.67 \\
\hline
\end{tabular}

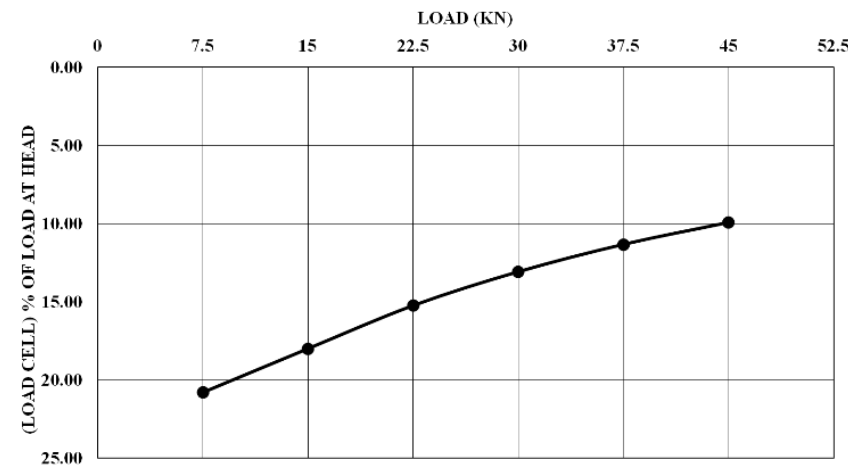

Fig 34: Relationship between applied load at pile head and transferred load to soil at pile tip measured by load cells, group (1) - (single pile) 


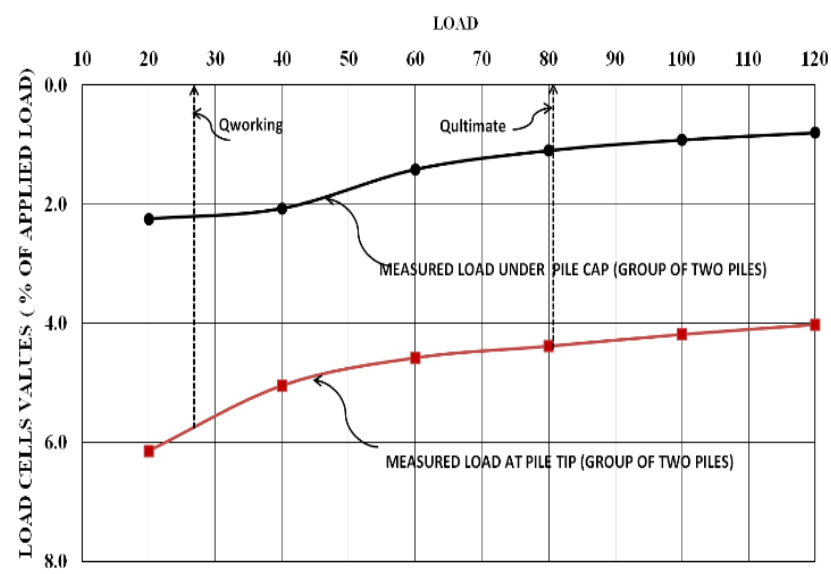

Fig 35: Relationship between applied load at pile head and transferred load to soil at pile tip and underneath pile cap measured by load cells, group (2) - (two piles)

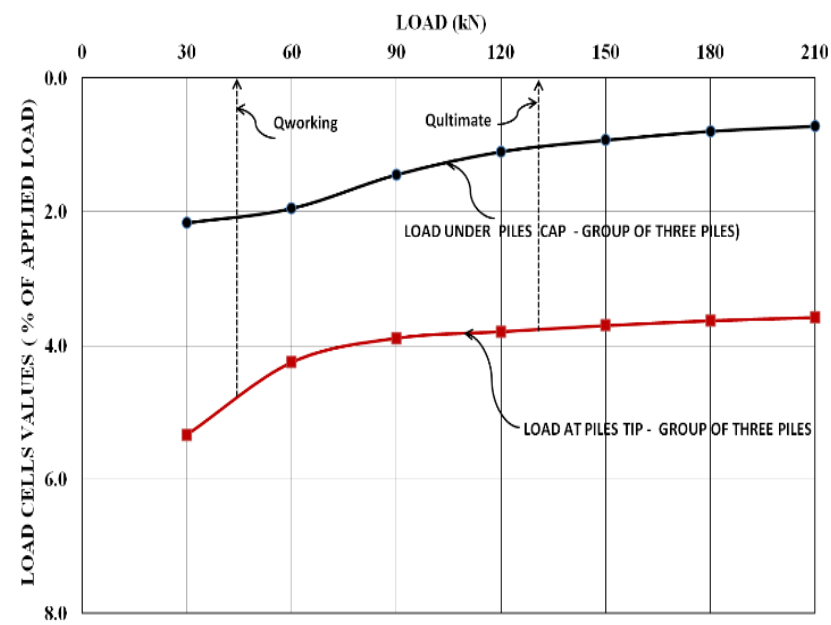

Fig 36: Relationship between applied load at pile head and transferred load to soil at pile tip and underneath pile cap measured by load cells, group (3) - (three piles)

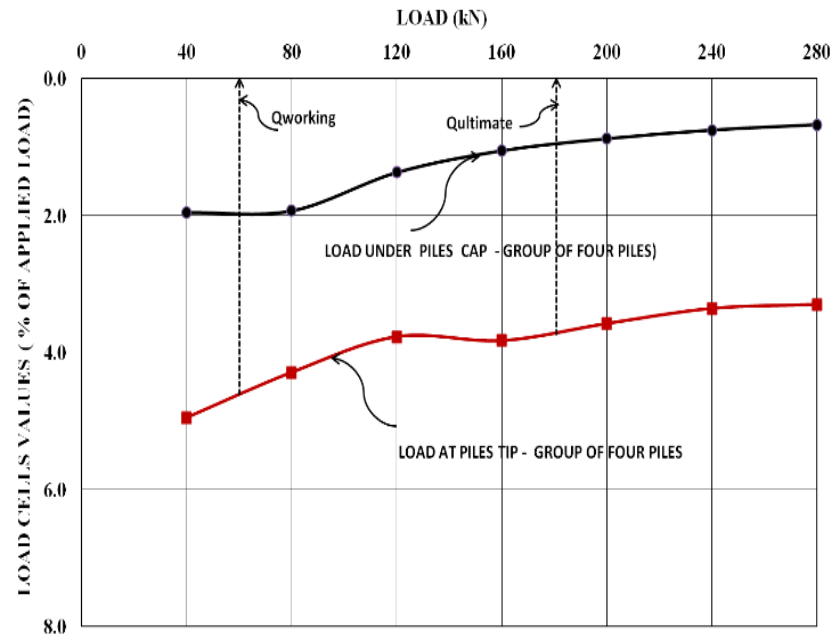

Fig 37: Relationship between applied load at pile head and transferred load to soil at pile tip and underneath pile cap measured by load cells, group (4) - (four piles)

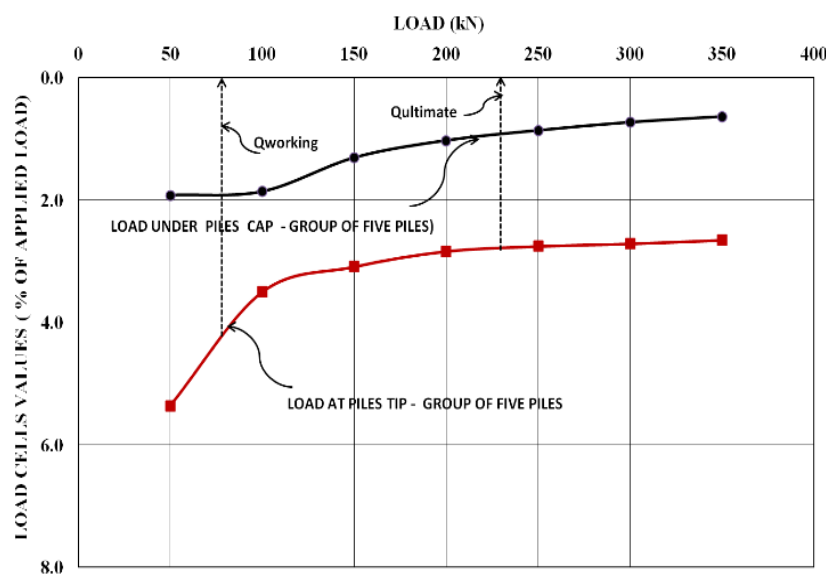

Fig 38: Relationship between applied load at pile head and transferred load to soil at pile tip and underneath pile cap measured by load cells, group (5) - (five piles)

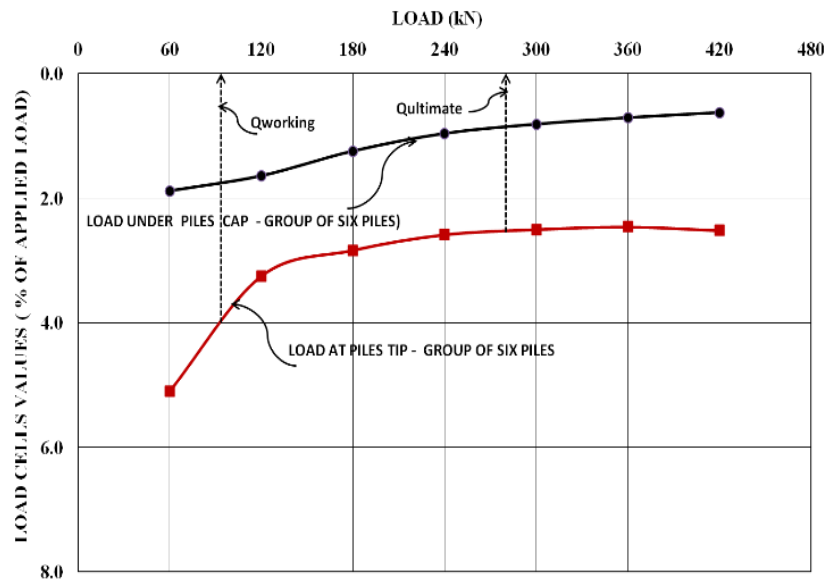

Fig 39: Relationship between applied load at pile head and transferred load to soil at pile tip and underneath pile cap measured by load cells, group (6) - (six piles)

For single pile and pile groups of (2, 3, 4, 5 and 6 piles), the transferred loads to soil around pile shaft (friction) as a percentage of ultimate load measured from load cells are listed in Table (5) and as a percentage of working loads are listed in Table (6). The relationships between the applying load at pile/piles head and distribution of load at pile/piles shaft are shown in Figures (40) to (45).

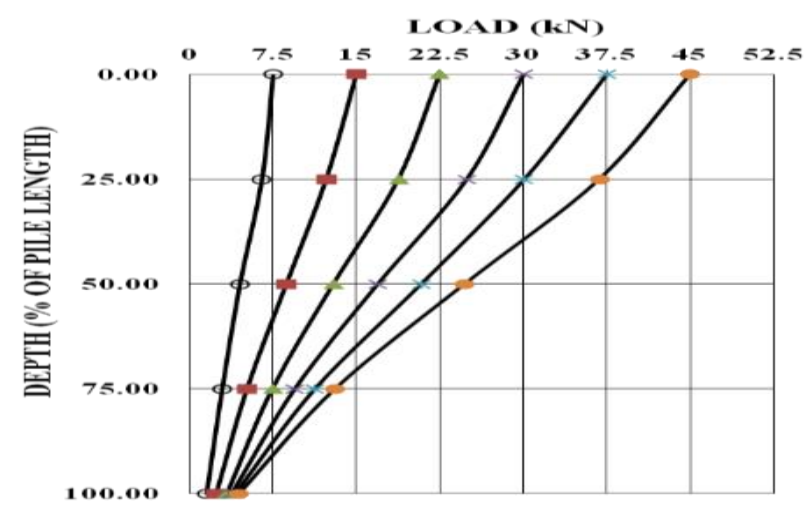

Fig 40: Distribution of load at pile shaft measured from strain gauges, group (1) - (single pile) 


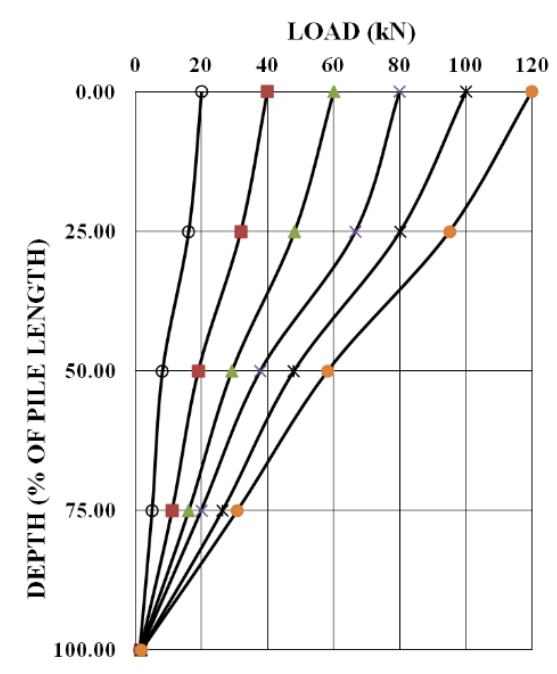

Fig 41: Distribution of load at piles shaft measured from strain gauges, group (2) - (two piles)

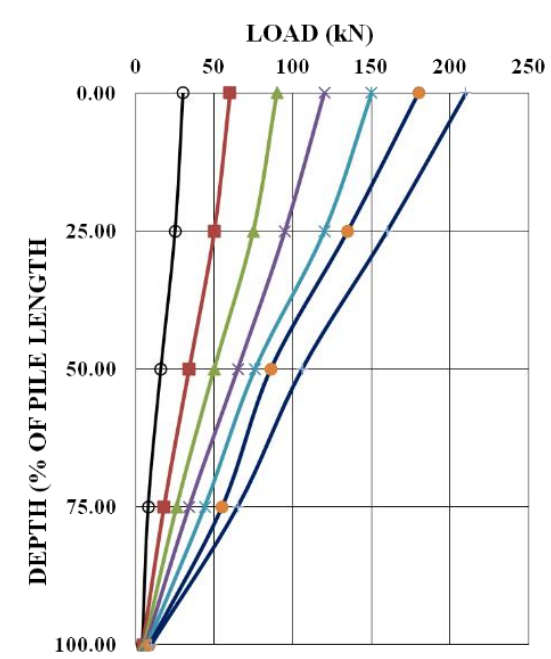

Fig 42: Distribution of load at piles shaft measured from strain gauges, group (3) - (three piles)

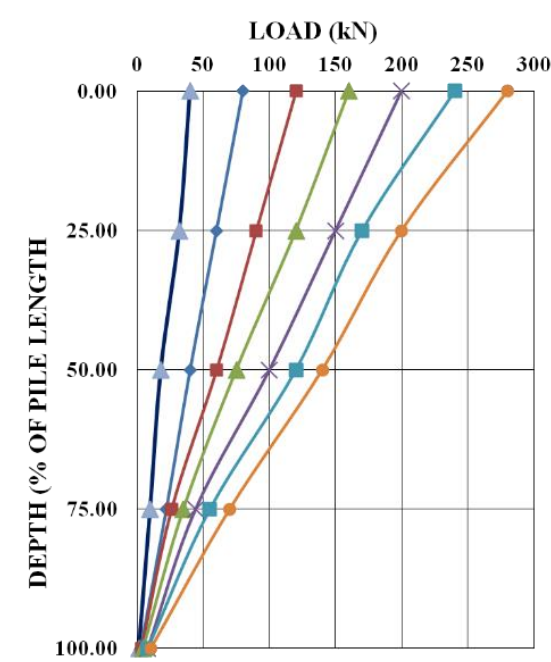

Fig 43: Distribution of load at piles shaft measured from strain gauges, group (4) - (four piles)

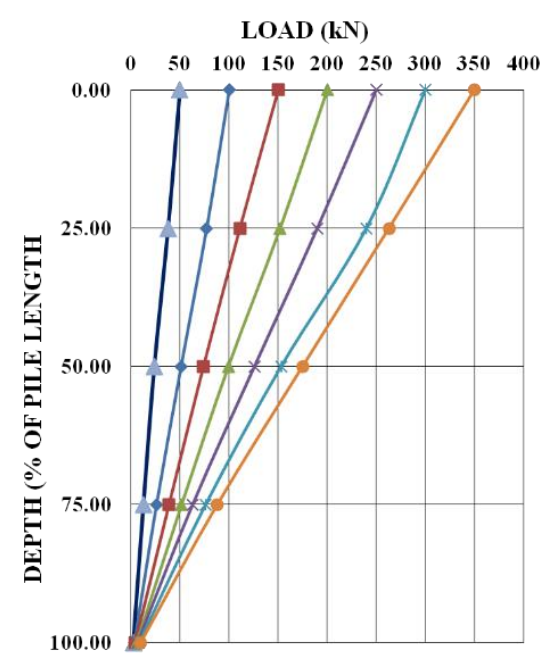

Fig 44: Distribution of load at piles shaft measured from strain gauges, group (5) - (five piles)

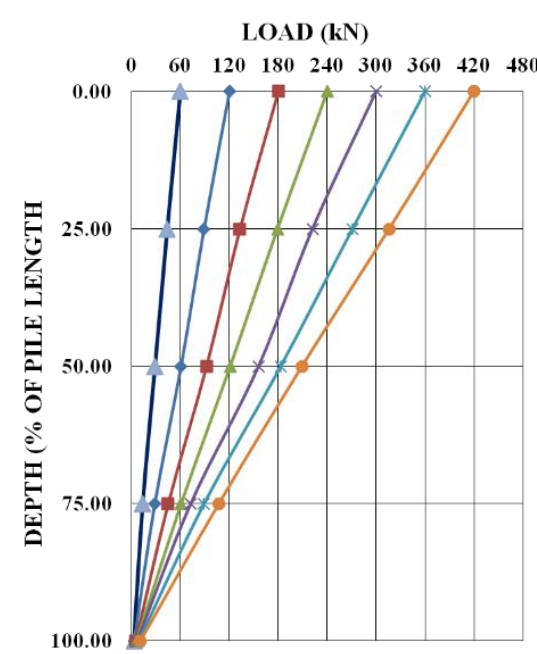

Fig 45: Distribution of load at piles shaft measured from strain gauges, group (6) - (six piles)

\section{ANALYSIS OF EXPERIMENTAL TEST RESULTS}

From the present study, the followings were obtained:

The distribution of loads around piles shaft (friction) at ultimate capacities obtained from tangent-tangent method is shown in Figure (46).

The relationship between number of piles in groups and the transferred loads to soil around piles shaft (friction) as percentage of ultimate load and working load presented in Tables (4) and (5) are shown in Figures (47) and (48). A comparison between the transferred loads to soil around pile shaft at ultimate load and working load is shown in Figure (49). 


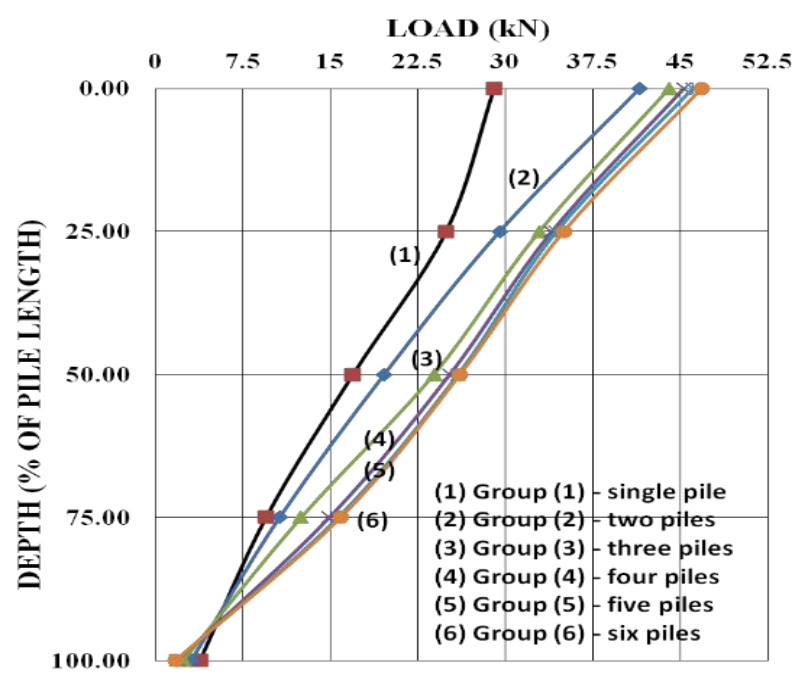

Fig 46: The distribution of loads around piles shaft (friction) at ultimate capacities obtained from tangent-tangent method

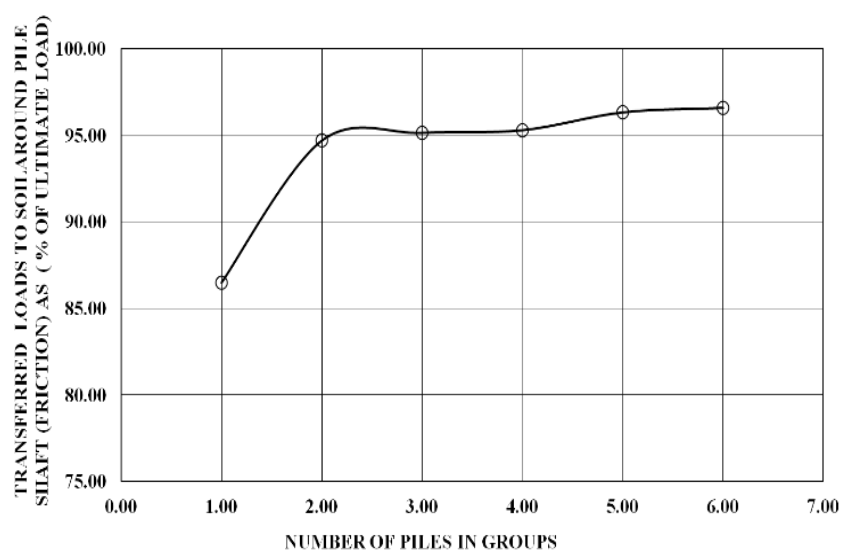

Fig 47: Relationship between number of piles in groups and the transferred loads to soil around pile shaft (friction) as percentage of ultimate capacities obtained from tangenttangent method

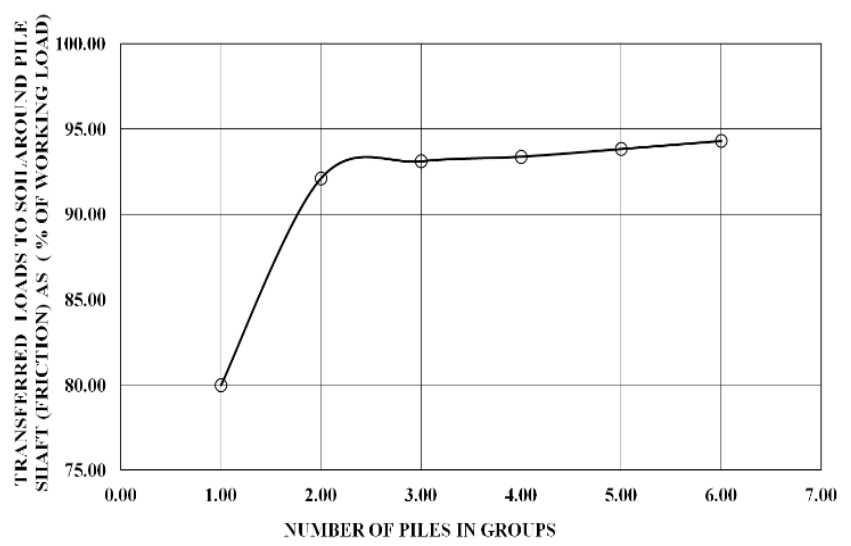

Fig 48: Relationship between number of piles in groups and the transferred loads to soil around pile shaft (friction) as percentage of working capacities obtained from tangenttangent method, (F.S. $=3.00)$

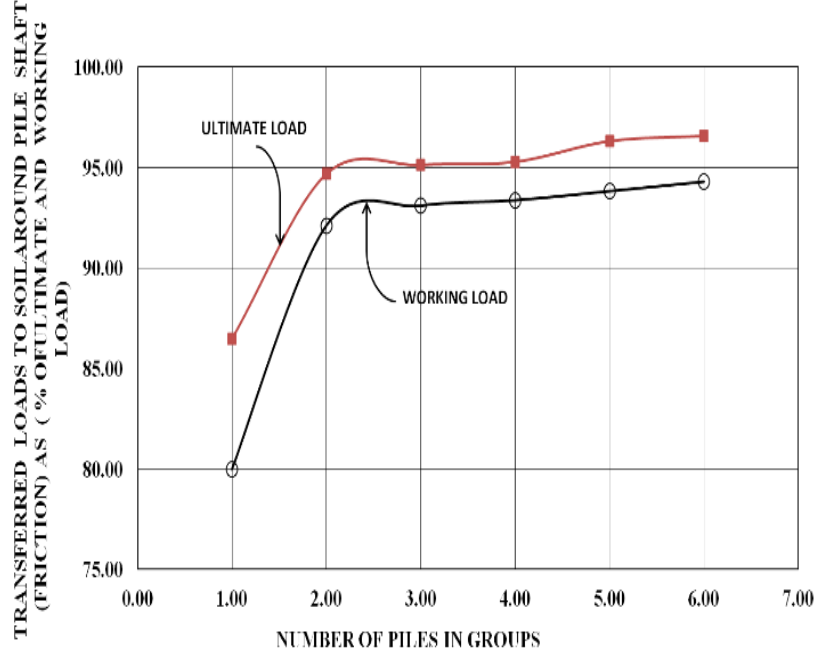

Fig 49: Comparison between transferred loads to soil around pile shaft (friction) as percentage of ultimate and working capacities obtained from tangent-tangent method, (F.S. = 3.00)

It was found that the transferred loads to soil at piles shaft (friction) are ranging from 86.50 to $96.59 \%$ at ultimate capacity. However, it was found to be ranging from 80.00 to $94.30 \%$ at working capacity by taking a factor of safety = 3.00 .

The transferred loads to soil underneath pile caps and at pile tips for groups (2, 3, 4, 5, and 6 piles) are shown in Figures (50) and (51).

The relationship between number of piles in groups and the transferred load to soil underneath pile caps and at pile tips as well as the relationship between number of piles in groups and the transferred load to soil at pile tip as a percentage of ultimate loads is shown in Figure (52).

The relationship between number of piles in groups and the transferred load to soil underneath pile caps and at pile tips as well as the relationship between number of piles in groups and the transferred load to soil at pile tip as a percentage of working loads is shown in Figure (53).

It was found that the loads transferred to soil underneath piles cap decreases with increasing the number of piles in group.

It was found that the loads transferred to soil at pile tip decreases with increasing the number of piles in group. However, the load resisted by friction around piles shaft increases with increasing the number of piles in group. 


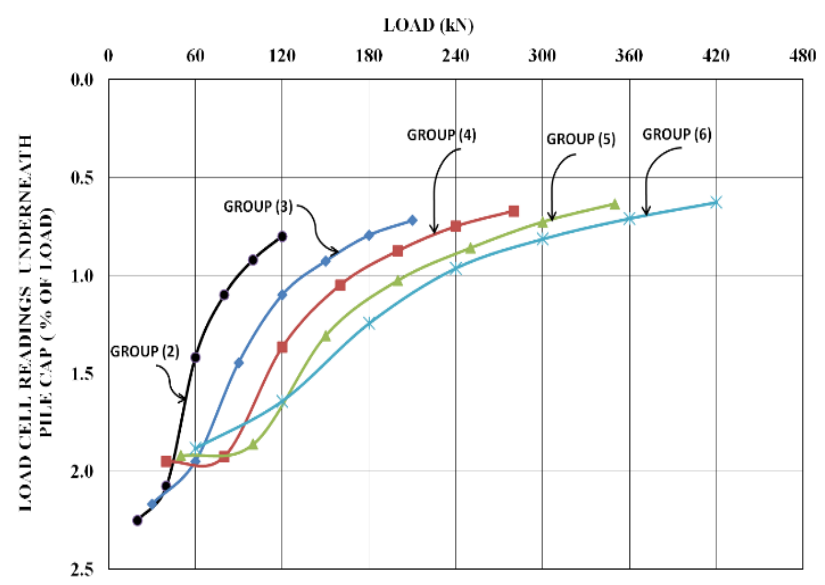

Fig 50: Transferred loads to soil underneath pile cap as a percentage of test loads increments measured by load cell unit, groups $(2,3,4,5$, and 6 piles $)$.

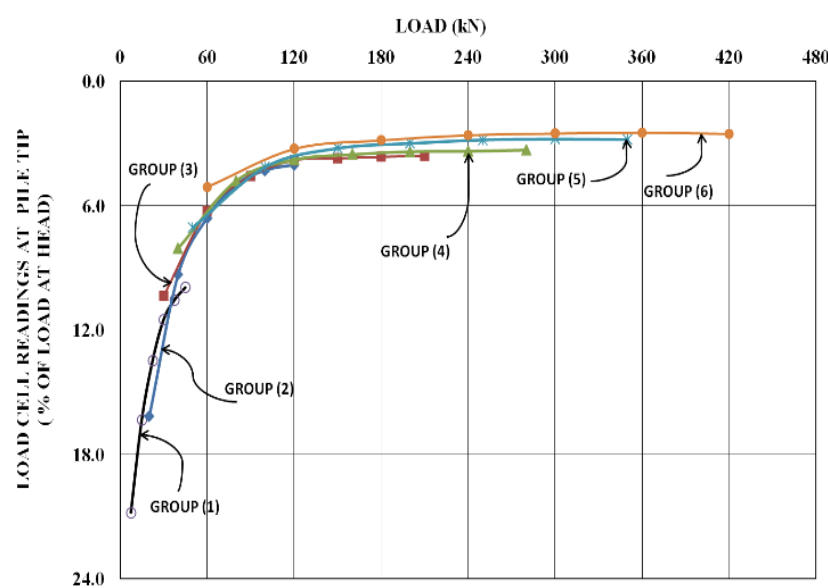

Fig 51: Transferred loads to soil at the pile tip as a percentage of test loads increments of pile groups $(2,3,4,5$, and 6 piles)

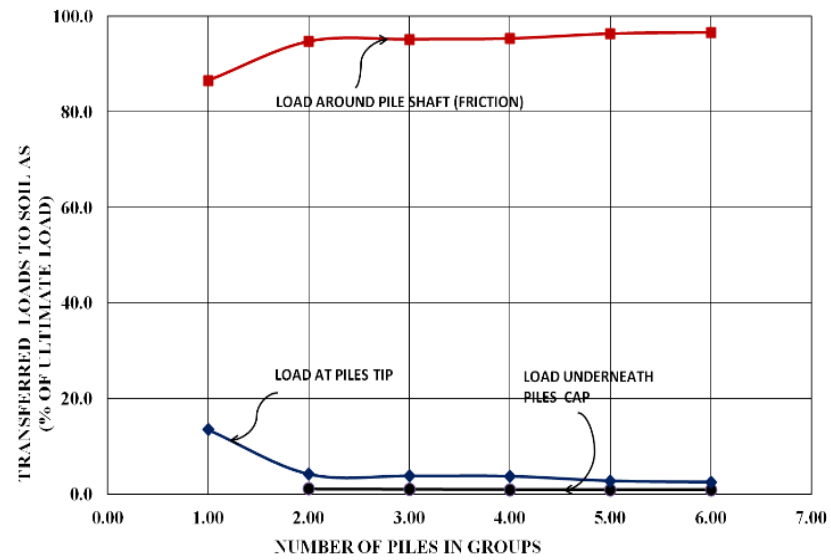

Fig 52: Relationships between number of piles in groups and the transferred loads to soil underneath pile cap, at pile tip and around pile shaft as a percentage of ultimate loads of single pile and pile groups (2, 3, 4, 5 and 6 piles) based on results of tangent-tangent method

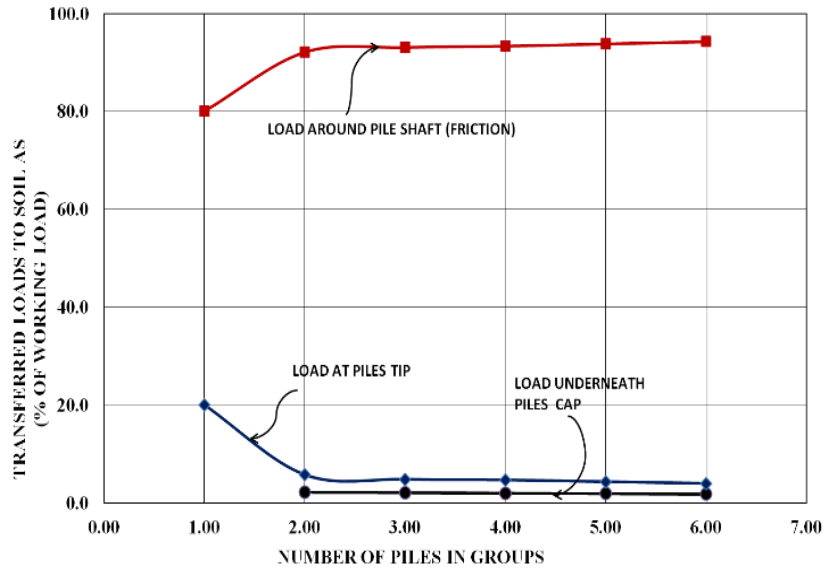

Fig 53: Relationships between number of piles in groups and the transferred loads to soil underneath pile cap, at pile tip and around pile shaft as a percentage of working loads of single pile and pile groups $(2,3,4,5$ and 6 piles) based on results of tangent-tangent method

A comparison between transferred loads to soil underneath pile cap and at pile tip as a percentage of ultimate and working loads of single pile and pile groups (2, 3, 4, 5 and 6 piles) based on results of tangent-tangent method is shown in Figure (54).

A comparison between transferred loads to soil around pile shaft as a percentage of ultimate and working loads of single pile and pile groups (2, 3, 4, 5 and 6 piles) based on results of tangent-tangent method is shown in Figure (55).

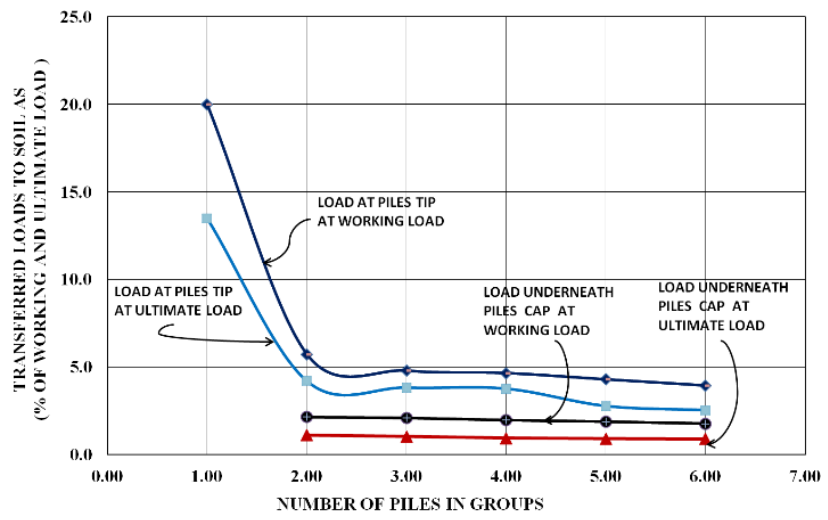

Fig 54: Comparison between transferred loads to soil underneath pile cap and at pile tip as a percentage of ultimate and working loads of single pile and pile groups (2, 3, 4, 5 and 6 piles) based on results of tangent-tangent method 


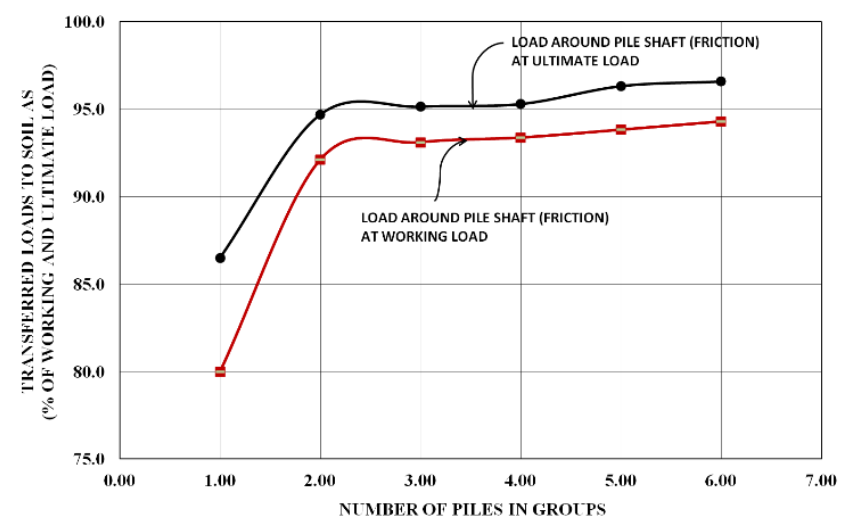

Fig 55: Comparison between transferred loads to soil around pile shaft as a percentage of ultimate and working loads of single pile and pile groups (2, 3, 4, 5 and 6 piles) based on results of tangent-tangent method

\section{CONCLUSION}

From the present investigationthe followings are concluded: It was found that the loads transferred to soil underneath piles cap decreases with increasing the number of piles in group.

It was found that the loads transferred to soil at pile tip decreases with increasing the number of piles in group. However, the load resisted by friction around piles shaft increases with increasing the number of piles in group.

For single pile, $86.50 \%$ of the applied ultimate load is resisted by side friction and $13.50 \%$ by tip resistance. However, it was found to be $80 \%$ resisted by side friction and $20 \%$ by tip resistance from the working load capacity (F.S. $=3.00)$.

For pile groups of $(2,3,4,5$ and 6 piles) the load transferred to soil by friction was found to be from $94.70 \%$ to 96.59 from the ultimate load capacity and from $92.12 \%$ to 94.30 from the working load capacity $($ F.S. $=3.00)$.

For pile groups of (2, 3, 4, 5 and 6 piles) the load transferred to soil at pile tip was found to be from $4.20 \%$ to 2.53 from the ultimate load capacity and from $5.73 \%$ to 3.94 from the working load capacity (F.S. = 3.00).

For pile groups of $(2,3,4,5$ and 6 piles) the load transferred to soil underneath piles cap was found to be from $1.10 \%$ to $0.88 \%$ from the ultimate capacity and from $2.15 \%$ to 1.76 $\%$ from the working load capacity (F.S. $=3.00$ ).

\section{REFERENCES}

[1] Russo, G. (1998), "Numerical Analysis Of Piled Rafts" International Journal For Numerical And Analytical Methods In Geomechanics, Int. J. Numer. Anal. Meth. Geomech., 22, 477- 493 (1998)

[2] Noh E. Y., Huang M., Adamec R., and Balasurbamaniam A. S. (2008), "Finite Element Modeling For Piled Raft Foundation In Sand" Eleventh East Asia-Pacific Conference on Structural,
Engineering \& Construction (EASEC-11), November 19-21, 2008, Taipei, TAIWAN.

[3] Amornfa K., Phienwej N., Kitpayuck P. (2012) " Current Practice On Foundation Design Of High-Rise Buildings In Bangkok, Thailand " Lowland Technology International Vol. 14, No. 2,70-83, December 2012

[4] Alnuiam A., El-Naggar H., El-Naggar M. H., (2013) " Performance of Piled-Raft System under Axial Load" Proceedings of the 18th International Conference on Soil Mechanics and Geotechnical Engineering, Paris 2013

[5] Park, D., Kyug, D., Choi, K., and Lee, J. (2013), "Analysis of Plie Raft Interaction in Sand With Centrifuge Tests" Seventh International Conference on Case Histories In Geotechnical Engineering, Missouri University of Scince and Technology.

[6] Park, D., Kyug, D., Park, D., Kim, I., and Lee, J. (2013), " Analysis of load sharing behavior for piled rafts using normalized load response model" The 15th Asian Regional Conference on, Japanese Geotechnical Society Special Publication

[7] Thakare, S. W., and Pankaj D. (2016), " Performance of Piled Raft Foundation on Sand Bed" International Journal of Innovative Research in Science, Engineering and Technology (IJIRSET).

[8] Ahmadi, M. M. (2016), "A new approach for group efficiency of drilled shafts in sand subjected to axial loading" International Journal of Geotechnical Engineering.

[9] Elsamny, M. K., Ibrahim, M. A., Gad, S. A., AbdMageed, M.F. (2017), "Experimental Evaluation of Bearing Capacity and Behaviour of Single Pile and Pile Group in Cohesionless Soil" International Journal of Engineering Research \& Technology (IJERT)ISSN: 2278-0181Vol. 6 Issue 5, May-2017

[10] Elsamny, M. K., Ibrahim, M. A., Gad, S. A., AbdMageed, M.F. (2017), "Experimental Study on Pile Groups Settlement and Efficiency in Cohesionless Soil" International Journal of Engineering Research \& Technology (IJERT)ISSN: 2278-0181Vol. 6 Issue 5, May-2017

[11] Egyptian Code for "Soil Mechanics and Foundation", Egypt (2001)

[12] Meyerhof, G. G. (1976), "Bearing Capacity and Settlement of Pile Foundations". JGED, ASCE, Vol. 102, GT 3.

[13] Vesic, A. S. (1977), "Design of Pile Foundations, Synthesis of Highway Practice" 42, Res. Bd., Washington D.C.

[14] Janbu, N. (1976), "Static Bearing Capacity of Friction Piles" Proceedings 6th European Conference on Soil Mechanics and Foundation Engineering Vol. 1-2. Pp $479-488$.

[15] Coyle, H. M., and Castello, R. R. (1981), "New Design Correlations for Piles in Sand" Journal of the Geotechnical Engineering Division, ASCE, Vol. 107, No. GT17. July p.p. $965-986$. 